\title{
TO FILTER, OR NOT TO FilTER? THAT IS THE QUESTION IN EU COPYRIGHT REFORM
}

\author{
Giancarlo Frosio*
}

forthcoming in 36(2) Cardozo Arts \& Entertainment Law Journal (2017)

\begin{abstract}
This article discusses the proposed introduction in EU law of an obligation for hosting providers to conclude licencing agreements with copyright holders and ensure their functioning by taking effective technological measures-such as content id technologies-to prevent copyright infringement on online platforms. This proposal is included in Article 13and accompanying Recitals - of the European Commission's Draft Directive on Copyright in the Digital Single Market of September 14, 2016, which forms an important part of the ongoing EU copyright reform. This article highlights the shortcoming of this proposed reform, which might fall short in terms of clarity, consistency with the EU acquis, appropriacy and proportionality. In doing so, the article discusses recent CJEU case lawsuch as GSMedia, Ziggo and Filmspeler-struggling with the notion of communication to the public in the digital environment. It highlights systemic inconsistencies between the traditional knowledge-and-take-down negligence-based intermediary liability system and the introduction of filtering and monitoring obligations. The article examines the appropriacy of filtering-and monitoring-measures within a fundamental rights perspective by considering proportionality between property rights' enforcement and competing fundamental rights-such as freedom of expression, freedom of business and privacy. The critical review of the proposed reform serves as an opportunity to briefly advance an alternative proposal seeking a more pragmatical engagement with technological change through an arrangement enforcing a liability rule or an apportionment of profits and producing value for creators out of platform economy's virality, while limiting negative externalities on users' rights.
\end{abstract}

\footnotetext{
* Giancarlo Frosio is a Senior Lecturer and Researcher at the Centre for International Intellectual Property Studies (CEIPI), University of Strasbourg; Non-resident Fellow, Stanford Law School CIS; S.J.D. and LL.M, Duke Law School; LL.M, Strathclyde University. This article is based on the Opinion of the Centre for International Intellectual Property Studies (CEIPI) at the University of Strasbourg on the European Commission's Proposal on Intermediary Liability for Copyright Infringement Online. Please note that most materials cited in this paper include an embedded link. The author can be reached at gcfrosio@ceipi.edu.
} 


\section{INTRODUCTION}

So-called intermediary liability regimes were introduced almost two decades ago on a fundamental assumption: the exclusion of a general obligation on online providers to monitor the information which they transmit or store or actively seek facts or circumstances indicating illegal activity. ${ }^{12}$ That general principle served as an umbrella safeguard to avoid online filtering and intermediaries' policing obligations. In addition, the eCommerce Directive imposed also to EU Member States the obligation of providing online intermediaries, both access and hosting providers, with exemptions to liability for wrongful activities committed by their users. Similar legal arrangements were introduced in multiple jurisdictions. ${ }^{3}$ After initial hesitation, and proposals to hold intermediaries fully liable for infringements occurring through their networks, ${ }^{4}$ liability exemptions were finally enacted under the assumption that online service providers should have been little encumbered by liability concerns in order to promote the emerging Internet market, possibly as a free speech friendly environment. However, to borrow and paraphrase the words of the immortal bard,

there's a ghost returning from the grave

that lingers in Europe today

and wonders whether to filter or not to filter

as part of a copyright reform that is on the way

With its Digital Single Market Strategy (DSMS), the European Commission has been considering narrowing the eCommerce Directive's horizontal liability limitations through a "fit for purpose" regulatory environment for platforms and

\footnotetext{
${ }^{1}$ See Directive 2000/31/EC of the European Parliament and of the Council of 8 June 2000 on certain legal aspects of information society services, in particular electronic commerce, in the Internal Market, 2000 O.J. (L 178) 1-16, at Art. 15.

${ }^{2}$ Id., at Art. 12-14.

${ }^{3}$ See eg Copyright Legislation Amendment Act 2004 (Cth), No. 154, Sch. 1 (Australia); Copyright Modernization Act, SC 2012, c20, § 31.1 (Canada); Judicial Interpretation No. 20 [2012] of the Supreme People's Court on Several Issues concerning the Application of Law in Hearing Civil Dispute Cases Involving Infringement of the Right of Dissemination on Information Networks, December 17, 2012 (China); Federal Law No. 149-FZ, on Information, Information Technologies and Protection of Information, July 27, 2006 (Russia) and Federal Law No. 187-FZ of July 2, 2013 amending Russian Civil Code, § 1253.1 (Russia); Communications Decency Act of 1996, 47 U.S.C. $§ 230$ (United States) (exempting intermediaries from liability for the speech they carry) and The Digital Millennium Copyright Act of 1998, 17 U.S.C. $§ 512$ (United States) [hereinafter DMCA] (introducing specific intermediary liability safe harbors for copyright infringement),

4 See BRUCE LEHMAN, INTELlECtUAL PROPERTy AND THE NATIONAL INFORMATION INFRASTRUCTURE: THE REPORT OF THE WORKING GROUP ON INTELLECTUAL PROPERTY RIGHTS (DIANE Publishing 1995) 114-124 (noting "the best policy is to hold the service provider liable [. . .] Service providers reap rewards for infringing activity. It is difficult to argue that they should not bear the responsibilities.']; see also James Boyle, Intellectual Property? Two Pasts and One Future, Information Influx International Conference, Amsterdam (July 2-4, 2014), <https://www.youtube.com/watch?v=gFDA-G_VqHo>.
} 
intermediaries. ${ }^{5}$ In particular, a copyright reform proposal under discussion before the EU Parliament would like to impose filtering and monitoring obligations on certain online platforms. ${ }^{6}$

The DSMS announced steps to be taken "towards a connected digital single market" and plans to reform EU copyright. ${ }^{7}$ Through a variety of policy interventions, the DSMS would like to move the EU from 28 national markets to a single one by "bringing down barriers to unlock online opportunities." ${ }^{8}$ Next to e-commerce and telecom rules, cross-border sales, ${ }^{9}$ interoperability and standardization, the DSMS does tackle copyright reform ${ }^{10}$ and the role of online intermediaries. ${ }^{11}$ The DSMS copyright related actions focus on three main issues, including (lack of) cross-border access to content and its portability, text and data mining for non-commercial and commercial purposes alike, and civil enforcement and the role of ISPs. In particular, the Commission noted that

5 See European Commission, Communication, A Digital Single Market Strategy for Europe, $\operatorname{COM}(2015) 192$ final, May 6, 2015, at $§ 3.3$ [hereinafter DSMS].

${ }^{6}$ Proposal for a Directive of the European Parliament and of the Council on Copyright in the Digital Single Market, COM(2016) 593 final (September 14, 2016), Art. 13 [hereinafter DSM Directive Proposal]. Please note that there are several proposed amendments from parliamentary Committees to the draft proposal as issued by the Commission. While this article focuses on the Commission proposal, proposed amendments will not be directly discussed but might be mentioned. So far, the Committee on the Internal Market and Consumer Protection (IMCO) approved an opinion. See Committee on the Internal Market and Consumer Protection (IMCO), Opinion for the Committee on Legal Affairs on the proposal for a directive of the European Parliament and of the Council on copyright in the Digital Single Market, 16 June 2017, PE 599.682v02-00, IMCO_AD(2017)599682. Also, the Culture and Education Committee (CULT) has approved its final opinion, which is still to be published. See Culture and Education Committee (CULT), Draft opinion on the proposal for a directive of the European Parliament and of the Council on copyright in the Digital Single Market, 6 February 2017, PE 595.591v01-00, CULT_PA(2017)595591. Finally, the Committee on Legal Affairs (JURI) also released a draft opinion and will vote on its amendments later this year. See Committee on Legal Affairs (JURI), Draft opinion on the proposal for a directive of the European Parliament and of the Council on copyright in the Digital Single Market, 10 March 2017, PE 601.094v01-00, JURI_PR(2017)601094.

${ }^{7}$ See DSMS, supra note 5,

${ }^{8}$ See European Commission, Priority, Digital Single Market, http://ec.europa.eu/priorities/digitalsingle-market_en.

${ }^{9}$ See Proposal for a Regulation of the European Parliament and of the Council on addressing geoblocking and other forms of discrimination based on customers' nationality, place of residence or place of establishment within the internal market and amending Regulation (EC) No 2006/2004 and Directive 2009/22/EC, $\operatorname{COM(2016)~} 289$ final (May 25, 2016) (preventing geo-blocking and other forms of discrimination).

${ }^{10}$ Regrettably, the Strategy does not tackle the issue of digital exhaustion.

11 The DSMS copyright related policy actions followed a draft report by MEP Julia Reda on the implementation of the InfoSoc Directive. See Report on the implementation of Directive 2001/29/EC of the European Parliament and of the Council of 22 May 2001 on the harmonization of certain aspects of copyright and related rights in the information society, 2014/2256(INI) (June 24, 2015) (rapporteur Julia Reda). 
[a]n effective and balanced civil enforcement system against commercial scale infringements of copyright is central to investment in innovation and job creation. In addition the rules applicable to activities of online intermediaries in relation to copyright protected works require clarification, given in particular the growing involvement of these intermediaries in content distribution. Measures to safeguard fair remuneration of creators also need to be considered in order to encourage the future generation of content. ${ }^{12}$

As a result, the European Commission proposed the introduction of enhanced obligations that websites and other Internet intermediaries should have for dealing with unlawful third-party content. ${ }^{13}$ In particular, the ongoing discussion would specifically refer to a subset of those intermediaries deemed "online platforms" and concentrates on "whether to require intermediaries to exercise greater responsibility and due diligence in the way they manage their networks and systems - a duty of care."14

The introduction of new obligations for online intermediaries as part of the most recent EU copyright reform proposal results from a number of policy actions that followed in the footsteps of the DSMS. First, the Commission released a new Communication, Towards a Modern, More European Copyright Framework. ${ }^{15}$ This Communication anticipated policy and legislative actions to

\footnotetext{
${ }^{12}$ Digital Single Market Strategy, supra note 5, at 2.4.

${ }^{13} I d$., at 3.3.2 (noting that "[r] ecent events have added to the public debate on whether to enhance the overall level of protection from illegal material on the Internet.")

${ }^{14}$ Id.. See also Directive 2001/29/EC of the European Parliament and of the Council of 22 May 2001 on the Harmonisation of Certain Aspects of Copyright and Related Rights in the Information Society, 2001 O.J. (L 167) 10-19, at Whereas 48 (previously establishing that "[t]his Directive does not affect the possibility for Member States of requiring service providers, who host information provided by recipients of their service, to apply duties of care, which can reasonably be expected from them and which are specified by national law, in order to detect and prevent certain types of illegal activities") (emphasis added). Accordingly, the implementation of some forms of "duty of care" for online intermediaries has been repeatedly put forward as a policy goal by European national jurisdictions. The German coalition agreement, for example, emphasized that "internet service providers should take more responsibility" for copyright mass infringements. See Deutschlands Zukunft gestalten - Koalitionsvertrag zwischen CDU, CSU und SPD, 18 Legislaturperiode (December 17, 2013), at 133-134 [hereinafter German Coalition Agreement], at 133-134. In particular, the grand coalition plans to "improve enforcement towards platforms whose business model is mainly based on the infringement of copyright" by ensuring "that such service providers no longer enjoy the general liability privilege as so-called hosting provider and in particular no longer receive advertising revenues." See German Coalition Agreement, supra note 14, at 133. See also Telemedia Act (TMA) of February 29, 2007, Federal Gazette I, 179, Sections 7 and 10 (English translation) (providing the general liability privilege insulating information service providers from copyright infringement claims for the acts of their users; GEMA v. RapidShare I ZR 80/12 (Bundesgerichtshof, August 15, 2013) (Germany) (finding that - under the TMA - host providers are already ineligible for the liability privilege if their business model is mainly based on copyright infringement) [hereinafter GEMA v. RapidShare].

15 See Communication from the Commission to the European Parliament, the Council, and the Economic and Social Committee, and the Committee of the Regions, Towards a Modern More European Copyright Framework, COM(2015) 260 Final, at 22-23 (December 9, 2015).
} 
adapt exceptions to digital and cross-borders environments. ${ }^{16}$ It sought clarifications in the domain of exclusive rights, including issues related to linking and considering whether any action specific to news aggregators is needed. ${ }^{17}$ Also, the Communication dealt with upcoming enforcement strategies, including "follow the money" strategies, commercial-scale infringements, application of provisional and precautionary measures, injunctions and their cross-border effect, and notice and action mechanisms, in particular the issue of action remaining effective over time - the "take down and stay down" principle. ${ }^{18}$

Meanwhile, the Commission also launched a public consultation on the evaluation and modernization of the legal framework for the enforcement of intellectual property rights. ${ }^{19}$ According to this Consultation, provisions established by the Enforcement Directive - such as the right of information, legal actions, damages and costs, and provisional and precautionary measures and injunctions - might soon be revisited. ${ }^{20}$ Also, the Commission launched a public consultation on the role and responsibilities of online intermediaries and platforms, a term which includes a broad range of websites and online services. ${ }^{21}$ In particular, Section 3 of the Consultation, Tackling Illegal Content Online and the Liability of Online Intermediaries, allowed to make a number of predictions regarding critical changes of the regulatory environment for intermediaries that might have been under review. It included inter alia questions about whether there should be imposed specific duties of care for certain intermediaries. ${ }^{22}$

\footnotetext{
${ }^{16} I d$., at 6-9. See also Proposal for a Regulation of the European Parliament and the Council, on Ensuring the Cross-border Portability of Online Content Services in the Internal Market, $\operatorname{COM}(2015627$ final (December 9, 2015). Cf. Christophe Geiger, Giancarlo Frosio, and Oleksandr Bulayenko, Opinion of the CEIPI on the European Commission's Proposal to Reform Copyright Limitations and Exceptions in the European Union (CEIPI Research Paper No. 2017-7, 2017).

${ }^{17}$ Id., at 9-10. See Giancarlo Frosio, Reforming Intermediary Liability in the Platform Economy: A European Digital Single Market Strategy, 112 NoRTHWESTERN U. L. REV. 19 (2017); Christophe Geiger, Oleksandr Bulayenko, and Giancarlo Frosio, The Introduction of a Neighbouring Right for Press Publisher at EU Level: The Unneeded (and Unwanted) Reform, 34(2) European Intel. Prop. Rev. 202 (2017); Christophe Geiger, Oleksandr Bulayenko, and Giancarlo Frosio, Reaction of CEIPI to the European Commission's Proposal on Neighbouring Rights for Press Publishers (CEIPI Research Paper No. 2016-01, December 2016).

${ }^{18} \mathrm{Id}$., at $10-11$.

${ }^{19}$ See European Commission, Public Consultation on the Evaluation and Modernisation of the Legal Framework for the Enforcement of Intellectual Property Rights (December 9, 2015) [hereinafter European Commission, Public Consultation on Modernization of Enforcement of IPRs].

${ }^{20}$ See Directive 2004/48/EC of the European Parliament and of the Council of 29 April 2004 on the enforcement of intellectual property rights, 2004 O.J. (L 195) 16 (Corrigendum) [hereinafter Enforcement Directive], Art. 3, 8, 9, 11, 13, and 14.

${ }^{21}$ See European Commission, Public consultation on the regulatory environment for platforms, online intermediaries, data and cloud computing and the collaborative economy (September 24, 2015), at 19 [hereinafter European Commission, Public Consultation on Online Intermediaries].

${ }^{22}$ Id., at 21-23.
} 
A consensus emerged from the consultation that the existing regime is considered fit for purpose. ${ }^{23}$ Therefore, the Commission published a Communication on Online Platforms and the Digital Single Market that apparently endorses the plan of maintaining the existing intermediary liability regime. ${ }^{24}$ However, the Commission stressed that "a number of specific issues relating to illegal and harmful content and activities online have been identified that need to be addressed." 25 In this context, the Commission would launch a "sectorial legislation [...] and problem-driven approach." ${ }^{26}$ This sectorial action will target inter alia copyright-protected content. ${ }^{27}$ This should happen through a mix of legislative interventions - by updating the copyright regulations - and promotion of voluntary self-regulatory actions. ${ }^{28}$ In particular, the OP\&DSM Communication anticipated modifications in the balance of copyright in favor of rightsholders as the Commission would aim to achieve a fairer allocation of value generated by the distribution of copyright-protected content by online platforms. ${ }^{29}$ The Commission presented this platform-sensitive update of the EU copyright policy in a proposal for a Directive on Copyright in the Digital Single Market, ${ }^{30}$ which is part of a larger package aiming at modernizing EU copyright rules and achieving a fully functioning Digital Single Market. ${ }^{31}$ While the reform has been discussed before the Parliament, the Commission issued an additional Communication that keeps pursuing "enhanced responsibility of online platforms." ${ }^{32}$ According to this last Communication, online intermediaries do

${ }^{23}$ See European Commission, Full Report on the Results of the Public Consultation on the Regulatory Environment for Platforms, Online Intermediaries and the Collaborative Economy, May 25, 2016 [hereinafter European Commission, Full Report on the Consultation on Online Intermediaries].

${ }^{24}$ See Communication from the Commission to the European Parliament, the Council, and the Economic and Social Committee, and the Committee of the Regions, Online Platforms and the Digital Single Market: Opportunities and Challenges for Europe, $\operatorname{COM(2016)~} 288$ Final, at 9 (May 25, 2016) [hereinafter OP\&DMS Communication]

${ }^{25} \mathrm{Id}$., at 8 .

26 See OP\&DMS Communication, supra note 24,8 .

$27 I d$.

${ }^{28} I d$.

${ }^{29} I d$. [emphasis added].

${ }^{30}$ See DSM Directive Proposal, supra 6.

${ }^{31}$ See European Commission, Digital Single Market, Modernization of the EU Copyright Rules, http://bit.ly/DSMCopyright16. See also Communication from the Commission to the European Parliament, the Council, and the Economic and Social Committee, Promoting a Fair, Efficient and Competitive European Copyright-based Economy in the Digital Single Market (COM)2016 592final (September 14, 2016) [hereinafter DSM Communication] (released in parallel with the DSM Directive Proposal).

${ }^{32}$ See Communication from the Commission to the European Parliament, the Council, and the Economic and Social Committee, and the Committee of the Regions, Tackling Illegal Content Online. Towards an enhanced responsibility of online platforms, COM(2017)555final (September 28, 2017). 
have a duty to provide a safe online environment to users by sanitizing it from illegal content promptly and proactively. ${ }^{33}$

The draft directive aims - inter alia - to close a so-called "value gap"-an alleged unfair distribution of revenues generated from the online use of copyright-protected works between the industry actors along the value chain. ${ }^{34}$ Rightholders would complain that-because of liability exemptions, no monitoring obligations, and the notice and take-down regime - they have no ability to monetize exchange of protected content on user-generated content and ad-funded platform such as YouTube, Dailymotion and Vimeo. Rather than entering into licencing agreements, UGC platforms can offer to remove infringing content upon notice-or possibly implement voluntary measures as YouTube Content ID. In turn-according to rightholders-other subscriptionfunded platforms such as Spotify or Netfix whose primary business is to sell content to users would be willing to pay less in licencing fees in order to remain competitive with UGC platforms. ${ }^{35}$

To the end of closing the "value gap," the proposed reform includes - at Art. 13 and Recitals 37-39 - a provision that would impact platform operations. It requires intermediaries "that store and provide access to large amounts of works [...] uploaded by their users"

(1) to take appropriate and proportionate measures "to ensure the functioning of agreements concluded with rightholders for the use of their works;" 36

(2) or "prevent the availability on their services of [such] works," including through "the use of effective content identification technologies;" 37

(3) "to provide rightsholders with adequate information on the functioning and the deployment of the measures, as well as, when relevant, adequate reporting on the recognition and use of the works;" 38 and

(4) put in place "complaints and redress mechanisms that are available to users in case of disputes over the application of the measures." ${ }^{39}$ Meanwhile, Member

\footnotetext{
${ }^{33} I d ., \S 3$ and 3.3.1.

${ }^{34}$ See DSM Communication, supra note 31 , at 7.

${ }^{36}$ DSM Directive Proposal, supra note 6, at Art. 13(1).

${ }^{37} I d$.

${ }^{38} I d$.

${ }^{39}$ Id., at Art. 13(2).
}

35 See Martin Husovec, EC Proposes Stay-down \& Expanded Obligation to Licence UGC Services, Hut'ko's Technology Law Blog, September 1, 2016, http://www.husovec.eu/2016/09/ec-proposes-stay-down-expanded.html (making an interesting point by noting that "[i]f hosts See notice-and-takedown as a real alternative to negotiations with right holders, perhaps it indicates that the music is not so indispensable for the online service. Right holders can expose services without such agreements to more enforcement, and so if the music would be so crucial, notorious take-downs would destroy its business.") 
States shall facilitate "stakeholder dialogues to define best practices, such as appropriate and proportionate content recognition technologies." 40

The policy goal of redistributing resources to creators for uses of their works in the platform economy would be undeniably a worthy one. After all, creatorsas long as they allow the European public to enjoy creative content in all ways made possible by digital technology - are the very goal of our copyright system. To that end, the promotion of agreements between creators and information society service providers should be pursued. Also, narrow and specific duties of care to detect and prevent infringing activities would be within the scope of EU law. However, the means that this proposal would like to deploy to reach its goals - together with the shaky empirical foundations of the notion of value gap - can find little support and justification within the EU legal system. This proposal lacks in clarity, consistency and adequacy for a number of reasons as highlighted in the next few pages.

\section{CLARITY}

A paramount issue with this proposal is one of terminology. Some wording would apparently lack in clarity and make hard to predict the implications of the implementation of the proposal. As worded, the proposal might upset - willingly or unwillingly - a number of previous construction of EU law on point —or at least lead to conclusions which are not pacifically granted. In particular, Recital 38(1-2) of the proposal-read together with Art. 13-might cause some interpretive headaches:

Where information society service providers store and provide access to the public to [large amounts of] copyright protected works or other subject-matter uploaded by their users, thereby going beyond the mere provision of physical facilities and performing an act of communication to the public, they are obliged to conclude licensing agreements with rightholders, unless they are eligible for the liability exemption provided in Article 14 of Directive 2000/31/EC [. . .] In respect of Article 14, it is necessary to verify whether the service provider plays an active role, including by optimising the presentation of the uploaded works or subject matter or promoting them, irrespective of the nature of the means used therefor. ${ }^{41}$

\section{On the Notion of Information Society Service Providers}

Which platforms are requested to enter into revenue-share agreements with right holders and collective societies or prevent access to protected works from their services through filtering? Does this proposal imply that a sharing platform like YouTube, Dailymotion or Soundcloud does not qualify as a passive host in the first place? ${ }^{42}$ Indeed, this is the interpretation that will be sought by

\footnotetext{
${ }^{40} I d$., at Art. 13(3).

${ }^{41}$ Id. Recital 38(1) (emphasis added).

${ }^{42}$ See Eleonora Rosati, Why a Reform of Hosting Providers' Safe harbour is Unnecessary under EU Copyright Law (CREATe Working Paper 2016/11, August 2016).
} 
rightholders, if this reform will come to force. In response to the draft reform, a music industry representative clarified:

PRS for Music welcomes the Commission's recognition of the critical 'transfer of value' issue and we acknowledge the clear intention to redress the current imbalance of interests between user upload platforms and rightsholders. The law must clearly establish that those user upload platforms that provide search and other functionality, as distinct from being mere hosts of content, require a license from rightsholders. The European Commission's proposed new copyright Directive provides the framework for this essential legal clarity. ${ }^{43}$

This proposal would like to impose a number of obligations - namely those at (1)-(4) above - to certain categories of intermediaries. The nature of these intermediaries would be supposedly defined in Article 13 and-especiallyRecital 38. Apparently, the new proposal would apply to active hosting providers. First, the proposal refers only to those who "store and provide access" to protected works - restricting therefore its scope to hosting providers. If they are not eligible for the liability exemption ex Article 14, eCommerce Directivewhich is that given to hosting providers - they will be obliged to conclude licensing agreements with rightholders. Second, for the exemption not to apply, the proposal assumes that hosting providers must play an active role. In defining an active hosting provider, the proposal states that it must go "beyond the mere provision of physical facilities." 44 Then, it redeploys the language in L'Oréal v. $e$ Bay by noting that "it is necessary to verify whether the service provider plays an active role, including by optimising the presentation of the uploaded works or subject matter or promoting them, irrespective of the nature of the means used therefor." 45 In referring to L'Oréal, the proposal does imply that not all active hosts would be excluded from the application of the hosting exemption. According to L'Oréal, Article 14 of the Directive applies to hosting providers if they don't play an active role that would allow them to have knowledge or control of the stored data. ${ }^{46}$ Therefore, a hosting provider can still be protected even if it is not completely passive - as long as it does not have knowledge or control over the data which is being stored. ${ }^{47}$

43 See PRS for Music Chief Executive responds to EU copyright reform plans, https://groups.google.com/forum/\#!topic/1709-copyright-blog/3W8F6prvezM

${ }^{44}$ DSM Directive Proposal, supra note 6, at Recital 38 (emphasis added).

${ }^{45} I d$. . See also L'Oréal SA and Others v. eBay International AG and Others, C-324/09, § 116 (ECJ, July 12, 2012).

${ }^{46}$ See L'Oréal, supra note 45, § 112-116. See also Patrick Van Eecke, Online Service Providers and Liability: A Plea for a Balanced Approach, 48(5) COMMON MARKET L. REV. 1455 (2011) (supporting a "storage but no knowledge" test and a restrictive interpretation of the requirement that intermediaries' activities are of a mere technical, automatic, and passive nature-based on Recital 42 of the E-commerce Directive - which would not extend to hosting providers, therefore as long as an active hosts does not have knowledge or control over the data which is being stored it could still be protected under Article 14 of the Directive 2001/29/EC).

${ }^{47} I d . \S 115$. 
In defining its scope of application, however the proposal rises several concerns that make hard to construe its full scope. First, the targeted providers are those that store and provide access to a large amount of copyright protected works uploaded by their users. It is quite a no brainer that the construction of the notion of "large amount" here might be a challenging interpretative conundrum. ${ }^{48}$ Apparently, a standard based on an indefinite quantitative measurement might prove a poor policy choice. At present, the scope of application of the new provision becomes impossible to determine. In passim, it should be noted that paragraph 1 of Recital 38 does not refer to large amounts of work. However, other text in the Recitals and Art. 13 do so. This might be an oversight - or at least little relevant in construing the category of intermediaries subject to the obligation of concluding licencing agreements - but could be critical in redefining the notion of communication to the public and whether it applies to works to which intermediaries and platforms provide access to the public as to be discussed later.

Second, the Recitals consistently mention that the obligations apply to intermediaries storing and providing public access to "copyright protected" works, while Article 13 drops the mention to infringing works altogether. On one side, this is an inconsistency that needs clarification. On the other, this different wording does matter, especially in connection with the notion of large amounts. Apparently, Article 13 would impose its obligations on intermediaries storing and providing public access to large amount of works, regardless of whether they are copyright protected or not. The notion of large amount would be construed looking at the totality of the content stored on the provider's system, rather than the infringing content. Hence, Article 13's obligations would cover intermediaries, such as Wikimedia, that might store only minimum amounts of infringing content - thus inconsequent to the supposed overreaching reform goal of closing the value gap.

Third, the notion of "providing access to the public" to content does need interpretation as it makes its first appearance in European intermediary liability theory. Apparently, in order to trigger the new obligations, intermediaries must provide access to the public to content by playing an active role according to the standards defined in L'Oreal - therefore by optimizing the presentation of the uploaded works or promoting them. At least, this conclusion could be drawn from Recital 38 clarifying that the new obligation covers only the intermediaries described above, and not those exempted from liability by Article 14 of the eCommerce Directive. ${ }^{49}$ In addition, the notion of "to the public" should most

\footnotetext{
${ }^{48}$ See Christina Angelopoulos, EU Copyright Reform: Outside the Safe Harbours, Intermediary Liability Capsizes into Incoherence, KLUwER COPYRIGHT BLOG, October 6, 2016, http://kluwercopyrightblog.com/2016/10/06/eu-copyright-reform-outside-safe-harboursintermediary-liability-capsizes-incoherence.

${ }^{49}$ DSM Directive Proposal, supra note 6, at Recital 38(1-2).
} 
likely follow the jurisprudence interpreting "communication and making available to the public." 50

\section{On Communication to the Public, Direct, and Secondary Liability}

There is another point then that has been taking the center stage in the debate surrounding the DSM Draft Directive's proposal, especially due to recent activism of the CJEU that might be aligning its jurisprudence to the positions held by the Commission in the proposal. Apparently, the proposal implies that if hosting providers do not just merely provide physical facilities, "thereby" they do perform an act of communication to the public. ${ }^{51}$ The Commission reinforced this statement also elsewhere. Calling for closing the value gap, the Communication on Online Platforms and the Digital Single Market noted that rebalancing is needed because "new forms of online content distribution have emerged [...] that may make copyright protected content uploaded by end-users widely available." 52 Apparently, the Commission characterizes platforms as actively "making available" content uploaded by end-users or performing an act of communication to the public. The reasons for this characterization are quite apparent. If platforms communicate to the public, they can be obliged to enter into licencing agreements, rather than monetization agreements on a voluntary basis. However, characterizing hosting providers as "communicating to the public" is a bold statement that has never been an obvious conclusion under EU law. ${ }^{53}$

First, the apparent implication that, unless liability exemptions apply, intermediaries storing and providing public access to protected works would be communicating to the public comes as a novelty. Actually, there is no direct relation between liability and exemptions, which function as an extra-layer of protection intended to harmonize at the EU level conditions to limit intermediary

\footnotetext{
${ }^{50}$ See eg Sociedad General de Autores y Editores de España (SGAE) v Rafael Hoteles SA, C306/05 § 37-42 (CJEU, 7 December 2006) (stating that the term 'public' (1) refers to an indeterminate number of potential recipients (2) implies, moreover, a fairly large number of persons (3) accounts must be given to the cumulative effects of making works available to potential audiences, and (4) the work must be communicated to a 'new public', that is to say, to a public which was not taken into account by the authors of the protected works when they authorised their use by the communication to the original public); and Reha Training Gesellschaft für Sport- und Unfallrehabilitation $\mathrm{mbH} \mathrm{v}$. Gesellschaft für musikalische Aufführungs- und mechanische Vervielfältigungsrechte (GEMA), C-117/15 §40-45 (CJEU, 31 May 2016).

${ }^{51}$ DSM Directive Proposal, supra note 6, at Recital 38(1).

52 OP\&DMS Communication, supra note 24, at 8 [emphasis added].

${ }^{53}$ See Angelopoulos, supra note 48 (noting that "for a nonchalant statement hidden in a recital, this is quite the dramatic development of EU copyright law"); Christina Angelopoulos, 'On Online Platforms and the Commission's New Proposal for a Directive on Copyright in the Digital Single $\quad$ Market' (2017) 19-33 <https://juliareda.eu/wpcontent/uploads/2017/03/angelopoulos_platforms_copyright_study.pdf $>$;
} 
liability. ${ }^{54}$ The inapplicability of the exemptions does not imply as such that information society service providers would be liable.

In addition, the construction of EU law included in the proposal would make hosting providers directly liable, rather than secondary liable. Communication to the public - according to Article 3 of the Infosoc Directive-includes making a work available to the public "in such a way that members of the public may access it from a place and at a time individually chosen by them." ${ }^{55}$ As the wording of the proposal acknowledges, the ECJ clarified that "the mere provision of physical facilities [. . .] does not as such amount to communication to the public." 56 Traditionally, the European Court of Justice emphasised the indispensable role of the user. In order to have a communication to the public, the user must - in full knowledge of the consequences of its actions - give access to the protected work to an additional public so that - absent that indispensable intervention - that 'new' public is unable to enjoy the works. ${ }^{57}$ Again, the ECJ stated that communication to the public does occur when content may be accessed by the public "only as a result of a deliberate intervention of that operator." 58 As end-users physically upload the work, they alone apparently can carry out that necessary indispensable deliberate intervention enabling the new public to enjoy the protected work. In this respect, online hosting providers could traditionally be distinguished from those users whose role ECJ jurisprudence found indispensable in communicating to the public. In Football Association Premier League, the ECJ found that a pub owner communicated to the public "when he intentionally transmits broadcast works, via a television screen and

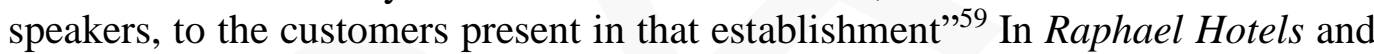
Phonographic Performance, communication to the public was made by hotel operators installing a TV set or a CD player in a hotel room and enabling the transmission of the signal to the guests. ${ }^{60}$ Again, Airfield NV and TVCatchup concerned broadcasting made available via satellite or over the Internet by a satellite package provider and an internet TV broadcasting service respectively. ${ }^{61}$ In these scenarios, the intervention of the users is necessary as they deliberately decide to transmit the content to their customers. Apparently, this is not the case with online hosting providers - regardless of whether they are active or passive. Hosting providers do not deliberately decide to transmit content. They offer a

\footnotetext{
${ }^{54} I d$.

${ }^{55}$ See Directive 2001/29/EC, supra note 14, Art. 3(1).

${ }^{56}$ See SGAE, supra note 50, at $\S 46$.

57 See SGAE, supra note 50, at $§ 42$; Football Association Premier League and Others v. QC Leisure and Others, C-403/08 and C-429/08, at $\$ 195$ (CJEU, 3 February 2011).

${ }^{58}$ See Phonographic Performance (Ireland) Limited v. Ireland, Attorney General, C-162/10 (15 March 2012) § 40.

${ }^{59}$ FAPL, supra note 57 , at $§ 196$.

${ }^{60}$ See Phonographic Performance, supra note 58, at $§ 66-69$; SGAE, supra note 50, at $\S 47$.

${ }^{61}$ See Joined Cases C-431/09 and C-432/09 Airfield NV v. SABAM (2011); C-607/11 ITV

Broadcasting v. TV Catchup (2012) ECLI:EU:C:2013:147
} 
platform where content is hosted. They have no role in deciding what does reach the platform's end-users. They do not make any material deliberation regarding the content that should reach the end-users. It is the end-users themselves that make that deliberation.

However, recent CJEU case law have been transitioning to an apparently looser standard, focusing on the essential, rather than the indispensable, role of the user. ${ }^{62}$ This, in turn, would make easier to construe hosting providers as communicating to the public. Recent CJEU case law qualified this notion of essential intervention by extending it to circumstances not only where, absent that intervention, customers would not be able to access the work but also where they "would be able to do so only with difficulty." 63 In particular, Ziggo concludes that without the operators of the platform "ThePirateBay" (TPB) making the platform available and managing it, the users could not share the works or, "at the very least, sharing them on the internet would prove to be more complex." 64

Actually, at national level, intermediaries have been already held directly liable for their users' copyright infringement, but only in residual circumstances when their involvement in the infringement is so substantial that they have been found to have communicated the works themselves, rather than being used by others to perform the communication. ${ }^{65}$ This line of argument might still distinguish Ziggo - and Wullems - from cases involving UGC platforms targeted by the upcoming reform. ${ }^{66}$ In Ziggo, the TPB provided a vast array of functions-

${ }^{62}$ See Case C-527/15, Stiching Brein v. Jack Frederik Wullems, ECLI:EU:C:2017:300 § 32 (finding communication to the public the sale of a multimedia player with pre-installed adds on, available on the internet, containing hyperlinks to freely accessible website making infringing materials available); Case C-610/15, Stichting Brein v. Ziggo BV, XS4ALL Internet BV, ECLI:EU:C:2017:456 § 37.

${ }^{63}$ See C-610/15, supra note 62 , at $\$ 26$.

${ }^{64} I d$., at $\S 36$.

${ }^{65}$ Standards have varied greatly from jurisdiction to jurisdiction. See Angelopoulos (2017), supra note 53, at 23-30. See eg France (implementing rather low standard to find intermediaries' direct liability). In the UK, there is clear distinction between primary and secondary infringement, which makes a high bar for finding intermediaries directly liable. See Twentieth Century Fox Film Corp v Newzbin Ltd [2010] EWHC 608 (Ch) (UK) (finding an indexing website-used for the illegal exchange of copyrighted movies - directly liable for having communicated works to the public because it had 'intervened in a highly material way to make the claimants' films available to a new audience, that is to say its premium members," in particular "by providing a sophisticated technical and editorial system which allows its premium members to download all the component messages of the film of their choice upon pressing a button, and so avoid days of (potentially futile) effort in Seeking to gather those messages together for themselves"); Football Association Premier League Ltd v British Sky Broadcasting Ltd \& Others [2013] EWHC 2058 (Ch) (UK) (finding that - in the case of a link aggregator of unlawfully streamed sport events-(i) the aggregation of a large number of streams (ii) the indexing of those streams for the convenience of the users (iii) the provision of a simple link to click in order to have access to the stream, and (iv) the fact that the stream is presented in FirstRow's frame or window makes the site directly liable for the communication).

${ }^{66}$ In particular, the similarities of the CJEU Ziggo decision and the UK case law mentioned above are striking. In FAPL, the Court found that even if FirstRow were not a direct infringer, it would 
such as indexing, categorization, deletion and filtering - that obviously set the platform apart from any mere provision of physical facilities and trespass into a conduct intentionally aimed at facilitating infringement. ${ }^{67}$ In both cases, the CJEU found a specific design to induce copyright infringement, including advertisement or operators' comments on blogs and forums encouraging users to access and download infringing content. ${ }^{68}$ It found that both technology were primarily designed to infringe copyright, considering, for example, that almost the totality of files shared on the TPB platform infringe copyright. ${ }^{69}$

Absent all these cumulative circumstances, traditionally, intermediaries have been held secondary liable, rather than primarily. In most EU jurisdiction, secondary liability requires highly demanding conditions that are derived from miscellaneous doctrines of tort law, ${ }^{70}$ such as the doctrines of joint tortfeasance, authorization, inducement, common design, contributory liability, vicarious liability, or extra-contractual liability. ${ }^{71}$ In contrast, apparently, intermediary

be jointly liable with the operators of the user generated content (UGC) websites that host the embedded streams and with the third-party streamers who digitally capture the streams and do the embedding. See FAPL, supra note 65) § 43-44. In previous rulings, UK courts have already held that "two or more persons may participate in a common design to infringe [copyright] rendering them jointly liable." See Newzbin, supra note 65) § 103. The Advocate General deploys a matching argument later upheld by the CJEU: in a situation like TPC, the intervention of their operators "meets the conditions of being necessary and deliberate, laid down in the case-law of the Court" and those operators should therefore "also be considered, simultaneously and jointly with the users of the network, as originating the making available to the public of works that are shared on the network without the consent of the copyright holders, if they are aware of that illegality and do not take action to make access to such works impossible." CJEU, C-610/15, Stichting Brein v. Ziggo BV, XS4ALL Internet BV (8 February 2017) (Opinion of Advocate General Szpunar), ECLI:EU:C:2017:99, § 53.

${ }^{67}$ See C-610/15, supra note 62 , at $\S 38$.

${ }^{68}$ See C-527/15, supra note 62, at $\S 18$ and 50; C-610/15, supra note 62, at $\S 45$. Cf MGM Studios, Inc. v. Grokster, Ltd., 545 U.S. 913 (2005).

${ }^{69}$ See C-610/15 (Opinion of Advocate General Szpunar), supra note 66, at $§ 23$.

${ }^{70}$ See Kamiel Koelman and Bernt Hugenholtz, Online Service Provider Liability for Copyright Infringement (WIPO Doc. OSP/LIA/1 Rev.1, 22 November 1999), at 5-8; BGB [German Civil Code], Art. 830 (governing joint tortfeasance, which is usually found by the German Supreme Court only if third parties have knowingly and intentionally combined with the primary wrongdoer to bring about the infringement, induced them to infringe or helped them in their infringement - generally intermediaries do not qualify, as they lack the essential mental element).

71 There is no caselaw and harmonized regulation on secondary liability for copyright infringement at the EU level. Each Member State has deployed differing and miscellaneous standards. See CHRISTINA ANGElOPOUlos, EuROPEAN INTERMEDIARY LIABILITY IN COPYRIGHT. A TORT-BASED ANALYSIS (Kluwer Law Int'l 2016); Tatiana-Eleni Synodinou, Intermediaries' Liability for Online Copyright Infringement in the EU: Evolutions and Confusions, 31 CoMP. L. \& SeC. REV. 57, 57-67 (2015); Christina Angelopoulos, Beyond the Safe Harbors: Harmonizing Substantive Intermediary Liability for Copyright Infringement in Europe, 3 INTEL. PROP. QUART. 254 (2013); Mari Männiko, Intermediary Service Providers' Liability Exemptions: Where Can We Draw the Line?, in REgulating ETECHNOLOGIES IN THE EUROPEAN UnION: NORMATIVE REALITIES AND TRENDS (Tanel Kerikmäe ed., Springer Int'l Publ. 2014), supra noting that comparative analysis show that the present legislation is too general and gives too much room for interpretation); Patrick Van Eecke, Online Service Providers and Liability: A Plea for a Balanced 
services would automatically be assumed to be infringing and directly liable for infringements materially committed by others. Obviously, recent CJEU case law

Approach, 48(5) COMMON MARKET L. REV. 1455, 145-1461 (2011) Broder Kleinschmidt, An International Comparison of ISP's Liabilities for Unlawful Third Party Content, 18(4) INTERNATIONAL JOURNAL OF LAW AND INFORMATION TECHNOLOGY 332, 345-353 (2010). In France, for example, general tort law principles have been relied upon to expand liability to additional actors, than the material infringer. Extra-contractual liability obliges to repair damages caused with fault or negligence (responsabilité délictuelle and quasi-délictuelle). Traditionally, intermediaries were placed under a duty to take all necessary measures to prevent infringement of others' rights in order to avoid liability. Later, the Cour de Cassation found this general dutythat derailed into a judicially made notice and stay-down system-uncompliant with the prohibition of general monitoring under EU law, therefore copyright holders must now monitor the content of websites themselves and notify intermediaries for each new infringement of protected content. Google France v. Bach films, Arrêt n ${ }^{\circ} 831$ (Cour de cassation, Première chambre civile, 12 July 2012; Google France v. Bac films, Arrêt n ${ }^{\circ} 828$ (Cour de cassation, Première chambre civile, 12 July 2012); ANDRÉ LUCAS, HENRI JACQUES LUCAS AND AGNÈS LUCAS-SCHLOETTER, TRAITÉ DE LA PROPRIÉTÉ LITTÉRAIRE ET ARTISTIQUE 901 (LexisNexis 4th ed, 2012); Angelopoulos, supra note, at $\S 2$. In UK law, intermediaries would be generally held liable for the infringements of their users, if they have either authorised those infringements, procured or induced them or acted pursuant to a common design with its users to achieve them. See CDPA 1988, $\$ 16$ (stating that a copyright in a work is also infringed by "any person who, without the licence of the copyright owner, authorises another person to do any of the restricted acts"). Claimants bringing suits against secondary infringers have to prove an additional mental element, i.e. that the defendant knew or had reason to believe that he was dealing with infringing copies, providing the means for making infringing copies or that the performances for which he had permitted the use of premises or had provided necessary apparatus was infringing. See Dramatico Entertainment Ltd v British Sky Broadcasting Ltd [2012] EWHC 268 (Ch) (20 February 2012) (UK); Sophie Stalla-Bourdillon, Liability Exemptions Wanted! Internet Intermediaries' Liability under UK Law, 7(4) J. INT'L COMM. L. \& TECH. 289, 293-299 (2012); Angelopoulos, supra note, at $\S 1$; Angelopoulos, supra note 48; Paul S. Davis, Accessory Liability: Protecting Intellectual Property Rights, 4 IPQ 390 (2011). In Germany, intermediary liability in copyright is almost invariably handled through the doctrine of Störerhaftung - as an alternative to joint torfeasance for which intermediaries hardly qualify. This doctrine - embedded in BGB, §1004 - grants a permanent injunctive relief to the proprietor against anybody who has caused an interference-störer means interferer-with the property, unless it would be unreasonable to burden the interferer with a duty to examine whether his behaviour could interfere with the (intellectual) property of a third person. See Rolex v Ebay/ Ricardo (Internet Auction I), I ZR 304/01, JurPC Web-Dok, 31 (BGH, 11 March 2004) (Germany); Kleinschmidt, supra note, at 346-347; Angelopoulos, supra note, at $\S 3$. Again, a recent Spanish copyright reform expanded intermediary liability by introducing, inter alia, doctrines of secondary liability_inducement, contributory and vicarious liability — in the Spanish legal system. See Real Decreto Legislativo (RDL) 1/1996, de 12 de abril, por el que se aprueba el texto refundido de la Ley de Propiedad Intelectual, regularizando, aclarando y armonizando las disposiciones legales vigentes sobre la materia, BOE-A-1996-8930, Art. 138, as amended by Ley 21/2014, de 4 de noviembre, BOE-A-2014-11404 (Spain) (imposing liability-unless the intermediary is sheltered by the Directive 2001/29/EC's exemptions - on anyone who either knowingly induces the infringement, or knowing or having reason to know about the infringement cooperates to it, or having a direct economic interest in the results of the infringement has the ability to control the infringer's conduct). 
reinforces the position upheld by the proposal, ${ }^{72}$ still it remains over-inclusive and stretches too far the notion of communication to the public.

Finally - as anticipated earlier - an additional textual issue should be mentioned. Recital 38(1) does not mention "large amounts" of copyright protected works. This is the sole instance in which intermediaries are not qualified as storing and providing public access to large amounts of works. As Article 13 does, it should not be of concern whether the obligation of concluding licencing agreements applies to other intermediaries than those dealing with large amounts of works - although as mentioned it is doubtful whether copyright protected or not. However, the missing mention of "large amounts" in Recital 38(1) might imply that the novel construction of communication to the public that has been apparently delineated in that Recital should apply to intermediaries at large, rather than to the narrower category of those which are subject to the obligations of this proposed reform.

\section{CONSISTENCY}

Inconsistency with the EU acquis - or lack of systemic coordination-might irremediably plague the proposal. Systemic inconsistencies do emerge insofar as the proposal imposes on intermediaries the implementation of effective content recognition technologies to prevent the availability of infringing content and "in order to ensure the functioning of any licensing agreement." 73 The proposal hints at technologies such as YouTube's Content ID or other automatic infringement assessment systems. Apparently, the proposal would force hosting providers to develop and deploy filtering systems, therefore de facto monitoring their networks. The promotion of automated filtering emerges as a primary goal on the EU Commission agenda, both on a mandatory and voluntary basis. ${ }^{74}$ According

\footnotetext{
72 See Eleonora Rosati, The CJEU Pirate Bay Judgment and its Impact on the Liability of Online Platforms, (2017) EIPR (forthcoming) 1 <https://papers.ssrn.com/abstract id=3006591> (noting that "[i]n relation to the current EU policy discussion of the so called 'value gap proposal', the judgment reinforces the position of the European Commission, especially the basic idea that the making available, by a hosting provider, of third-party uploaded copyright content may fall within the scope of the right of communication to the public").

${ }^{73}$ DSM Directive Proposal, supra note 6, at Whereas 38.

74 These EU proposals follows in the footsteps of a well-established path in recent global intermediary liability policy. Recent case law has imposed proactive monitor obligations on intermediaries for copyright infringement. APC et al v Google, Microsoft, Yahoo!, Bouygues et $\mathrm{Al}$ (TGI Paris 2013) (France) (imposing on search engines an obligation to proactively expunge their search results from any link to the illegal movie streaming website Allostreaming and affiliated enterprises); Google Brazil v. Dafra, Special Appeal 1306157/SP (Superior Court of Justice, March 24, 2014) (Brazil) (imposing on YouTube a proactive monitoring obligation and a strict liability standard for infringement of Dafra's copyright in a commercial dubbed by an anonymous user with comments tarnishing Dafra's reputation); GEMA v. RapidShare, I ZR 80/12 (Bundesgerichtshof, August 15, 2013) (Germany) (finding that — under the TMA — host providers are already ineligible for the liability privilege if their business model is mainly based on copyright infringement); Zhong Qin Wen v. Baidu, 2014 Gao Min Zhong Zi 2045 (Beijing Higher People's Court 2014) (finding that it was reasonable for Baidu to exercise a duty to monitor and examine the legal status of an uploaded work once it has been viewed or downloaded
} 
to the recent Communication "Tackling Illegal Content Online. Towards an enhanced responsibility of online platforms," hosting providers would be called to adopt effective voluntary "proactive measures to detect and remove illegal content online" 75 and are encouraged to do so by using automatic detection and filtering technologies. ${ }^{76}$

\section{On Monitoring Obligations and eCommerce Directive}

At first glance, the introduction of any filtering technology - which would de facto impose general monitoring obligations as in order to filter unwanted content, all content must be monitored ${ }^{77}$ - would inevitably call into question necessary coordination with the eCommerce Directive. ${ }^{78}$ In this respect, the

more than a certain times). Actually, the emerging enforcement of proactive monitoring obligations have been spanning the entire spectrum of intermediary liability subject matters: intellectual property, privacy, defamation, and hate/dangerous speech. See Google v Mosley (TGI Paris, 6 November 2013) (France); Max Mosley v. Google Inc., 324 O 264/11 (Hamburg District Court, 24 January 2014), available at http://openjur.de/u/674344.html; Mosley v Google [2015] EWHC 59 (QB) (United Kingdom) (courts in France, Germany, and the UK imposing proactive monitoring obligations to search engines, which were ordered to expunge the Internet from pictures infringing the privacy rights of Max Mosley - former president of Formula 1 - caught on camera to have sex with prostitutes wearing Nazi paraphernalia); Rolex v. eBay (a.k.a. Internetversteigerung II), I ZR 35/04 (BGH, 19 April 2007) (Germany); Rolex v. Ricardo (a.k.a. Internetversteigerung III), Case I ZR 73/05 (BGH, April 30, 2008) (Germany) (in the so-called Internet Auction cases I-III, the German Federal Court of Justice-Bundesgerichtshofrepeatedly decided that notified trade mark infringements oblige internet auction platforms such as eBay to investigate future offerings - manually or through software filters - in order to avoid trade mark infringement); Delfi AS v Estonia No 64569/09 (ECtHR, June 16, 2015) (finding compliant with ECHR a decision imposing monitoring obligation on a news web portal for defamatory users' comments). In this context, however, notable exceptions-such as the landmark Belen case in Argentina-highlight also a fragmented international response to intermediary liability. See Rodriguez M. Belen v. Google, R.522.XLIX. (Supreme Court, October 29, 2014) (Argentina) (ejecting filtering obligations to prevent infringing links from appearing in search engines' results in the future in a case brought by a well-known public figure for violation of her copyright, honor and privacy). See also Giancarlo Frosio, The Death of No-Monitoring Obligations: A Story of Untameable Monsters, 8 JIPTEC (forthcoming, 2017), available at https://papers.ssrn.com/abstract_id=2980786.

${ }^{75}$ Communication, supra note 32 , at $\S 3.3 .1$ (noting that adopting such voluntary proactive measures does not lead the online platform to automatically lose the hosting liability exemption provided by the eCommerce Directive).

76 ibid $\S 3.3 .2$.

77 See C-360/10 Belgische Vereniging van Auteurs, Componisten en Uitgevers CVBA (SABAM) v Netlog $N V$ [2012] § 36-38 (noting that "it is common ground that implementation of that filtering system would require [...] active observation of files stored by users with the hosting service provider and would involve almost all of the information thus stored and all of the service users of that provider [. . .] [i]n the light of the foregoing, it must be held that the injunction imposed on the hosting service provider requiring it to install the contested filtering system would oblige it to actively monitor almost all the data relating to all of its service users in order to prevent any future infringement of intellectual-property rights").

${ }^{78}$ See Angelopoulos, supra note 53, at 33-38. 
proposed reform might go beyond the scope of the copyright review, trespassing into the domain of the eCommerce regulation. Apparently, Art. 13 of the proposal would contradict the intermediary liability exemption regime - in particular the no-monitoring obligation set out in Article 15 of the eCommerce Directive. ${ }^{79}$ The eCommerce Directive prohibits general monitoring obligations, although it does allow national law to provide for monitoring obligations "in a specific case." ${ }^{80} \mathrm{In}$ truth, eCommerce Directives also acknowledges that Member State can impose duties of care on hosting providers "in order to detect and prevent certain types of illegal activities." ${ }^{81}$ However, their scope should not extend to anything close to general monitoring obligations, if any meaning should be given to the previous statement in Recital 47 that only specific monitoring obligations are allowed. Also, duties of care should "reasonably be expected from the service provides," the Directive states, and no general monitoring obligation can fulfil such an expectation as they are explicitly ban by the Directive itself. In order to distinguish general from specific monitoring obligation, it should be considered that (1) as an exception, specific monitoring obligations must be interpreted narrowly, (2) both the scope of the possible infringements and the amount of infringements that can be reasonably expected to be identified, must be sufficiently narrow, and (3) it must be obvious which materials constitutes an infringement. ${ }^{82}$ As Van Eecke noted

[i]f [clear criteria] are not defined, or only vague criteria are defined by the court (e.g. "remove all illegal videos"), or if criteria are defined that would oblige the hosting provider to necessarily investigate each and every video on its systems (e.g. "remove all racist videos"), or if the service provider were required also to remove all variations in the future (e.g. "remove this video, but also all other videos that belong to the same repertory"), a general monitoring obligation would be imposed. ${ }^{83}$

The proposed obligation in Art. 13 would fall doubtless within the general category, rather than the specific.

Ça va sans dire, the proposal conflicts openly with consistent-and unambiguous-European jurisprudence. The European Court of Justice reinforced multiple times the position that there is no room for general proactive monitoring and filtering mechanisms under EU law. ${ }^{84}$ In the $S A B A M$ cases as well as L'Oreal, the court decided over the appropriacy and proportionality of injunctions issued under the Enforcement Directive and concluded plainly that

\footnotetext{
${ }^{79} I d$., at Art 14-15.

${ }^{80}$ See Directive 2001/29/EC, supra note 14, at Art. 14(3) and Recital 47.

${ }^{81} I d$., at Recital 48.

${ }^{82}$ See Van Eecke, supra note 65, at 1486-1487.

${ }^{83} \mathrm{Id}$., at 1487.

${ }^{84}$ See Scarlet Extended SA v. Société belge des auteurs, compositeurs et éditeurs SCRL (SABAM), Case C-70/10 (ECJ, November 24, 2011) (Europe) (re-stating the principles in favour of access providers); SABAM v. Netlog, supra note 77 (confirming the principle in favour of hosting providers).
} 
the eCommerce Directive limits conflicting measures that can be taken under other intellectual property legislation. ${ }^{85}$ In Netlog, the Court decided the matter with specific reference to hosting providers. Netlog's language unmistakably covers the proposal in Art. 13. According to the ECJ, European law must be interpreted as precluding to require a hosting provider to install a system for filtering: (1) information which is stored on its servers by its service users; (2) which applies indiscriminately to all of those users; (3) as a preventative measure; (4) exclusively at its expense; and (5) for an unlimited period, (6) which is capable of identifying electronic files containing musical, cinematographic or audio-visual works. ${ }^{86}$

According to the CJEU, room for proactive monitoring obligations Seems extremely limited within the EU legal framework. In L 'Oréal v. eBay, the ECJ did not discuss whether knowledge of a current infringement would require the hosting provider to prevent similar infringements in the future. Instead, the Court clarifies that any measure imposed on a hosting provider must be effective and dissuasive,${ }^{87}$ fair, proportionate and not excessively costly, ${ }^{88}$ must not create barriers to legitimate trade ${ }^{89}$ and — above all—must not boil down to a monitoring obligation. ${ }^{90}$ The ECJ therefore Seems to conclude that, "with respect to an injunction to prevent future infringements, all these criteria will only be simultaneously met in very specific situations." "S1 Some aid in construing the ECJ position might come from the Advocate General Jiiiiskinen Opinion. The Advocate General explicitly excluded both negligence and future infringements qualifying as actual knowledge:

[i]t also seems to me that legally 'knowledge' may refer only to past and/or present but not to the future [and] the requirement of actual knowledge Seems to exclude construed knowledge. It is not enough that the service provider ought to have known or has good reasons to suspect illegal activity. ${ }^{92}$

Accordingly, the fact that a trade mark has been infringed by a first user, does not imply that the hosting provider would have actual knowledge of a second user's infringement of the same trade mark. Similarly, the fact that a user is found to infringe a first trade mark, does not imply that the hosting provider can be deemed to have actual knowledge of the same user infringing a second trade

\footnotetext{
${ }^{85}$ See L'Oréal, supra note 45 , at $\S 139$; Scarlet, supra note 77 , at $\S 40$; Netlog, supra note 77 , at $\S$ 52.

${ }^{86}$ See Netlog, supra note 77 , at $\S 26$ and 52.

${ }^{87}$ C-324/09, supra note 45 , at $\S 136$.

${ }^{88}$ Id., at $\S 139$.

${ }^{89} I d$., at $\S 140$.

${ }^{90} I d$., at $\S 139$.

${ }^{91}$ Van Eecke, supra note 65, at 1476-1478

${ }^{92}$ L'Oréal v. eBay (Advocate General Opinion), at § 162-163.
} 
mark. ${ }^{93}$ By way of counterexample, the only situation in which the Advocate General would envisage "actual knowledge" would be in case of "double identity," i.e. the situation when the same user infringes the same trade mark in the same way within a short period of time. ${ }^{94}$ From his cautious wording in this regard, it is clear that such double identity circumstances are exceptional.

In addition, the proposal mentions that these filtering obligations should also apply when the providers "are eligible for the liability exemption provided in Article 14 of Directive 2000/31/EC." 95 This statement is hardly intelligible. First, why so, if the filtering obligation is imposed "to ensure the functioning of any licencing agreement"? ${ }^{96}$ Supposedly, licencing agreement obligations would only fall upon those active hosting providers, which are not covered by the liability exemption set out by Article 14 of the eCommerce Directive. If hosting providers are eligible for the liability exemption, they do not have to conclude revenueshare agreements, therefore they cannot be imposed filtering obligations to ensure the functioning of agreements that they are under no obligation to conclude.

This apparently meaningless reference to the hosting exemption in Article 14 still maintains intact all inconsistencies with the no-monitoring obligations in Article 15 of the eCommerce Directive. Actually, an earlier draft of the proposal extended the application of the filtering obligation also "when, in accordance with Article 15 of Directive 2000/31/EC, the online service providers do not have a general obligation to monitor the information which they transmit or store or to actively Seek facts or circumstances indicating illegal activity." 97 The new wording might confirm that there is definitely no consensus in reforming the no monitoring obligation principle. ${ }^{98}$ Still the Commission would like to introduce a provision that would impose proactive monitoring obligations and, therefore, can hardly coexist with the arrangement included in the eCommerce Directive.

Finally, this proposal would bring about an even more marked systemic inconsistency within EU law. As such, the proposal would deploy a strict liability regime, rather than a negligence-based regime. ${ }^{99}$ At present, the eCommerce

\footnotetext{
${ }^{93} I d$., at $\$ 166$.

${ }^{94} I d$., at $\S 167$.

${ }^{95}$ DSM Directive Proposal, supra note 6, at Whereas 38.

${ }^{96} I d$.

${ }^{97}$ See Husovec, supra note 35 (embedding in the blog post the previous draft).

${ }^{98}$ European Commission, Full Report on the Consultation on Online Intermediaries, supra note 23.

99 One might fairly argue here that strict-liability does not descend from third-party copyright infringement but rather from the violation of the stand-alone obligation of taking measures to prevent the availability of infringing works. If this is the case, technically, one might not refer to strict-liability for others' copyright infringement. This might matter a lot as hosting providers might be deemed liable for not implementing measures despite copyright infringement does occur or not. In this respect, hosting providers might be requested to implement measures that prevent the availability of works regardless their privileged use status. The current wording of the proposed Article 13 makes this construction likely by referring to preventing the availability of
} 
intermediary liability regime can be categorized as a negligence regime based on actual or constructive knowledge. ${ }^{100}$ The hosting exemption works according to a notice and take down regime. ${ }^{101}$ Upon knowledge of the infringement occurring through its services, the intermediary must act expeditiously to remove the infringing materials. Hosting providers shall be liable for failing to take appropriate and proportionate measures, such as effective content recognition technologies, to ensure protection of copyrighted works and prevent the availability of infringing materials on their networks. Apparently, regardless hosting providers' negligence, ineffective prevention of availability on their network of infringing content would make them liable. The proposal would make knowledge and take-down irrelevant for copyright purposes, de facto tearing apart the eCommerce Directive, which will be however-please note-still in full force! What will happen when intermediaries will come before a court claiming that, there is no liability as they are not negligent according to the eCommerce Directive, while rightholders will claim that intermediaries are liable as they should have filtered out infringing content regardless of any knowledge according to the Copyright in the Digital Single Market Directive?

This is not to say that the Commission cannot introduce proactive monitoring or a strict liability regime if it wishes to do so and finds the necessary consensus - although as to be explained in a moment this might be a poor policy choice. However, doing so solely through copyright regulation will be at odds with other portions of EU law, especially in light of the fact that the CJEU specifically recognized that monitoring obligations to prevent copyright infringement would be in violation of the eCommerce Directive. In additionregardless of whether this reform shall be implemented with or without amending the eCommerce Directive - this proposed provision oddly conflicts with the bold

\footnotetext{
'works or other subject-matter identified by rightholders through the cooperation with the service providers', rather than copyright protected works or other subject matters. However, the proposal might be harder to decipher in this respect. According to Recital 38, intermediaries do have an obligation to conclude licencing agreements and should take measures to ensure the functioning of those agreements. Prevention of copyright infringement does ensure the functioning of the agreements. Thus, hosting provider should take measures to prevent copyright infringement to ensure the functioning of the licencing agreements. Measures to be taken here are just conducive to enforce the primary obligation to conclude licencing agreements and ensure their functioning through copyright infringement prevention. So, by ineffectively taking measures to prevent availability of infringing works on their networks, hosting providers would be liable for their obligation to conclude and ensure functioning of licencing agreements. As that functioning depends on preventing third-party copyright infringement occurring through their networks, an argument can be made that providers' - strict - liability steams from those third-party torts. If the proposal is approved as it stands, this teleological interpretation might be preferred in light of the purpose and legal goals of the provision.

${ }^{100}$ See Pablo Baistrocchi, Liability of Intermediary Service Providers in the EU Directive on Electronic Commerce, 19 SANTA ClARA High TECH. L.J. 111, 114 (2002).

${ }^{101}$ See Directive 2001/29/EC, supra note 14, at Art. 14.
} 
statement made in the OP \& DSM Communication that "[t]he Commission will maintain the existing intermediary liability regime."102

\section{On Redress Mechanism and a Missing Notice and Take-Down Regime}

The second paragraph of Article 13 would also state that "Member States shall ensure that the service providers referred to in paragraph 1 put in place complaints and redress mechanisms that are available to users in case of disputes over the application of the measures referred to in paragraph 1." 103 This obligation to implement a redress mechanism for filtering measures does need clarification and might again trigger internal inconsistencies. First, a redress mechanism that resembles so closely a counter-notice would be expected to follow a notice. However, this is not the case as Article 13 would like to set up a proactive filtering mechanism that as such does not seek any individualized notice for infringing works but rather some other identification mechanismperhaps agreed in advance between rightholders and hosting providers. But, is this really the case? How would filtering measures work in practice? Should intermediaries filter everything under the sun? Should they proactively monitor what has been originally the subject of a notice? Should they apply recognition technologies only to a pre-existing black list of protected works? This might be the case - at least guessing a possible meaning of the reference in Article 13 to works 'identified by rightholders through the cooperation with the service provider', whose availability should be prevented. ${ }^{104}$ Who will provide that list? Who will update it? How? Little - or better nothing - is known at the moment. The proposal does not develop further on how this redress mechanism should work in practice. In particular, it does not provide for the development of best practices or standardization for complaints, while it does so for filtering mechanisms. ${ }^{105}$ Most likely, the final arrangement of this redress system might result from voluntary efforts and best practices promoted by the industry alone and might resemble closely a sectorial notice-and-take down system. Finally, this proposal would set up a counter-notice mechanism for filtering absent a EU-wide legislatively mandated horizontal notice-and-take-down and counter-notice

\footnotetext{
102 OP\&DMS Communication, supra note 24, at 9.

${ }^{103}$ DSM Directive Proposal, supra note 6, at Art. 13(2).

${ }^{104}$ DSM Directive Proposal, supra note 6, at Art 13(1). A leaked draft report to the Parliament from the Directive rapporteur, MEP Therese Comodini Cachia, tried to clarify this point by redrafting Article 13 so that for the purpose of taking 'appropriate and proportionate measures to ensure the functioning of agreements concluded with rightholders for the use of their works', 'rightholders shall provide service providers with accurately identified works or subject matter over which they enjoy rights'. See Draft Report by MEP Therese Comodini Cachia on the Directive on Copyright in the Digital Single Market for the Legal Affairs (JURI) Committee, Amendment 55-56.
}

${ }^{105}$ Id., at Art. 13(3). See also Husovec, supra note 35. 
system. ${ }^{106}$ Rather-for sake of systemic consistency-EU law should set up first the long-awaited notice-and-take-down system under the eCommerce Directive framework. ${ }^{107}$

However, this is apparently not an option on the Commission agenda. As mentioned in the OP\&DSM Communication, EU-wide notice-and-action procedures will be postponed for now as the Commission will assess the impact of on-going reforms first. ${ }^{108}$ In the future, a couple of alternatives might be looming ahead according to previous consultations and communications. First, a sectorial and problem-driven approach might also be implemented for notice-andaction procedures with special emphasis on different requirements as regards the content of the notice. ${ }^{109}$ According to the results to the Consultation on Online Intermediaries, respondents agree that different categories of illegal content require different policy approaches as regards notice-and-action procedures, especially for infringements of intellectual property rights, child abuse content and racist and xenophobic speech. ${ }^{110}$ Second, the Enforcement Directive might also be amended to explicitly establish that national courts must be allowed to order intermediaries to take measures aimed not only at bringing to an end infringements already committed against IPR using their services, but also at preventing further infringements. In that respect, according to the Consultation on Modernization of IPRs' Enforcement, the Directive should establish criteria on how "take down and stay down" should be undertaken without establishing a

\footnotetext{
106 See Directive 2001/29/EC, supra note 14, at Art. 21 (foreseeing the possibility of the introduction of a complete notice-and-take-down procedure); Leaked draft Proposal for a Directive of the European Parliament and of the Council on procedures for notifying and acting on illegal content hosted by online intermediary service providers ("Directive on notice-andaction procedures") [...] (2013) XXX draft (proposing a horizontal notice-and-action mechanism for hosting providers and later floated by the Commission). See also Aleksandra Kuczerawy, Intermediary Liability \& Freedom of Expression: Recent Developments in the EU Notice \& Action Initiative, 31(1) COMPUTER LAW AND SECURITY REVIEW 46 (2015).

${ }^{107}$ See Copyright Reform: Open Letter from European Research Centres, EU Copyright Reform Proposals Unfit for the Digital Age (24 February 2017) <http://bit.ly/2loFISF> and Angelopoulos (2017), supra note 53, at 43-44 (both suggesting the introduction of a horizontal notice-and-action framework for hosting providers instead of the current Art. 13).

108 See OP\&DMS Communication, supra note 24, at 9.

${ }^{109}$ It cannot be foreseen which categories might get a special treatment, however the Consultation mentioned the following categories: illegal offer of goods and services (e.g. illegal arms, fake medicines, dangerous products, unauthorised gambling services etc.); illegal promotion of goods and services; content facilitating phishing, pharming or hacking, infringements of intellectual property rights (e.g. copyright and related rights, trademarks); infringement of consumer protection rules, such as fraudulent or misleading offers; infringement of safety and security requirements; racist and xenophobic speech; homophobic and other kinds of hate speech; child abuse content; terrorism-related content (e.g. content inciting the commitment of terrorist offences and training material), and defamation. See Public Consultation on Online Intermediaries, supra note 21 at 19-20. See also German Coalition Agreement, supra note 14, at 133 (stipulating different liability levels for different kind of hosting providers);

${ }^{110}$ See European Commission, Brief Result of the Consultation on Online Intermediaries, supra note 23 .
} 
general monitoring obligation. ${ }^{111}$ The Communication Tackling Illegal Content Online reinforces this point on the agenda by endorsing "automatic stay-down procedures" to fingerprint and filter out content which has been already identified and assessed as illegal. ${ }^{112}$ However, how this can be done without general monitoring, it remains to be seen, as already discussed at length earlier.

\section{On Monitoring Obligations and Fundamental Rights}

As stated by multiple authority, ${ }^{113}$ general filtering and monitoring obligations would be inconsistent with the Charter of Fundamental Rights of the European Union. ${ }^{114}$ In the SABAM cases, the Court explained that filtering measures - and monitoring obligations - would fail to strike a 'fair balance' between copyright and other fundamental rights. ${ }^{115}$ In particular, they would undermine users' freedom of expression and right to privacy ${ }^{116}$ and the provider's freedom to conduct a business. ${ }^{117}$ The extent to which filtering and monitoring obligations do clash with rights of users and intermediaries - and therefore their inappropriacy as a policy option — will be subject of consideration in the next few pages.

\section{APPROPRIACY AND PROPORTIONALITY}

The numerous systemic inconsistencies that the reform will bring abouttogether with obscure textual references - reflect also on the appropriacy and proportionality of the reform. Actually, most arguments challenging the appropriacy of filtering and monitoring obligations have been plainly spelled out by the European jurisprudence itself, discussing the impossible coexistence between these measures and multiple fundamental rights. Also, the overall goal of the reform might finally be fundamentally inappropriate. The lack of empirical

\footnotetext{
${ }^{111}$ See European Commission, Public Consultation on Modernization of Enforcement of IPRs, supra note 19, at C.2.3.

${ }^{112}$ See Communication, supra note 32 , at $\S 5.2$.

${ }^{113}$ See Netlog, supra note 84. See also Angelopoulos (2017), supra note 56) 38-40; Stefan Kulk and Frederik J. Zuiderveen Borgesius, Filtering for Copyright Enforcement in Europe after the Sabam Cases, 34 Europ. InTELl. Prop. ReV. 791, 791-794 (2012); Darren Meale (Case Comment) SABAM v Scarlet: Of Course Blanket Filtering of the Internet Is Unlawful, But This Isn't the End of the Story, 37 Europ. InTEll. Prop. ReV. 429, 432 (2012); Andrea Montanari, Prime Impressioni sul Caso SABAM c. Netlog NV: gli Internet Service Provider e la Tutela del Diritto D'autore Online, 26(4) Diritto del Commercio Internazionale 1082 (2012); Evangelia Psychogiopoulou (Case Comment) Copyright Enforcement, Human Rights Protection and the Responsibilities of Internet Service Providers After Scarlet, 38 Europ. InTELl. Prop. REV. 552, 555 (2012).

114 See Charter of Fundamental Rights of the European Union, C326/391 (26 October 2012) [hereinafter EU Charter].

115 See Netlog, supra note 84 , at $\S 51$.

116 See EU Charter, supra note 114, at Art. 8 and 11.

117 See EU Charter, supra note 114, at Art. 16.
} 
support behind the notion of value gap challenges its appropriacy and proportionality.

\section{On Filtering/Monitoring and Fundamental Rights}

A major concern with the proposal is whether these content recognition technologies would be "appropriate and proportionate" for the task as the proposal would suggest. ${ }^{118}$ Apparently, they are not. As mentioned, these technologies - and the filtering and monitoring obligations that they bring about-would fail to strike a fair balance between copyright and other fundamental rights. This very point has been made explicitly clear by consistent jurisprudence of the ECJ that highlighted how the deployment of these technologies would be inappropriate by disproportionally favouring property rights against other fundamental rights.

\section{a. On Freedom of Information, Exceptions and Limitations, and Public Domain}

Users' freedom to receive and impart information would be struck by the proposal. Actually, automatic infringement assessment systems might undermine the enjoyment of users' exceptions and limitations. ${ }^{119}$ DRM effects on exceptions and limitations have been highlighted by copious literature. ${ }^{120}$ Similar conclusions apply to this scenario. Automated systems cannot replace human judgment that should flag a certain use as fair-or falling within the scope of an exception or limitation. Also, complexities regarding the public domain status of certain works might escape the discerning capacity of content recognition technologies. At the present level of technological sophistication, false positives might cause relevant chilling effects and negatively impact users' fundamental right to freedom of expression. In the own word of the European Court of Justice, these measures

\footnotetext{
${ }^{118}$ DSM Directive Proposal, supra note 6, at Art. 13(1).

119 See Leron Solomon, Fair Users or Content Abusers? The Automatic Flagging of NonInfringing Videos by Content ID on Youtube, 44 HoFSTRA L. REV. 237 (2015); Corinne Hui Yun Tan, Lawrence Lessig v Liberation Music Pty Ltd-YouTube's Hand (or Bots) in the Over-zealous Enforcement of Copyright, 36(6) E.I.P.R. 347, 347-351 (2014; Justyna Zygmunt, To Teach a Machine a Sense of Art - Problems with Automated Methods of Fighting Copyright Infringements on the Example of YouTube Content ID, Machine Ethics and Machine Law EProceedings, Jagiellonin University, Cracow, Poland, November 18-19, 2016, pp. 55-56; Zoe Carpou, Robots, Pirates, and the Rise of the Automated Takedown Regime: Using the DMCA to Fight Piracy and Protect End-Users, 39 COLUM. J. L. \& ARTs 551, 564-582 (2016).

120 See GiAnCARlo F. Frosio, COMMUNIA FinAl REPORT ON THE DigitAl PUBLIC DOMAIN 99103, 135-141 (report prepared for the European Commission on behalf of the COMMUNIA Network and the NEXA Center) (2011), http://www.communia-project.eu/final-report (discussing most of the relevant literature and major threats that technological protection measures pose for fair dealings, privileged and fair uses).
} 
could potentially undermine freedom of information, since that system might not distinguish adequately between unlawful content and lawful content, with the result that its introduction could lead to the blocking of lawful communications. Indeed, it is not contested that the reply to the question whether a transmission is lawful also depends on the application of statutory exceptions to copyright which vary from one Member State to another. In addition, in some Member States certain works fall within the public domain or may be posted online free of charge by the authors concerned. ${ }^{121}$

In this regard, it is worth noting an additional possible inconsistency that this reform might bring about. Recital 46 of the eCommerce Directive explicitly requires the hosting provider to respect the principle of freedom of expression when deciding about a take-down request. ${ }^{122}$ As respect of freedom of expression cannot be guaranteed by the adoption of automated filtering technologies, hosting providers would be incompliant with this obligation steaming from the eCommerce Directive, while filtering in compliance with the proposed directive.

In addition-besides mentioned EU law systemic inconsistenciesintroducing a strict liability system for online intermediaries' activities might be itself an inappropriate and disproportionate policy choice as it will upset the delicate balance of copyright protection with other fundamental users' rights. In Google v. Vuitton, the Advocate General of the CIEU pointed at the fact that general rules of civil liability (based on negligence) — rather than strict liability IP law rules - suit best the governance of the activities of Internet intermediaries. His argument — crafted in the context of trademark infringement online-would apply mutatis mutandis to copyright as well:

[1]iability rules are more appropriate, since they do not fundamentally change the decentralised nature of the internet by giving trade mark proprietors general and virtually absolute - control over the use in cyberspace of keywords which correspond to their trade marks. Instead of being able to prevent, through trade mark protection, any possible use - including, as has been observed, many lawful and even desirable uses - trade mark proprietors would have to point to specific instances giving rise to Google's liability in the context of illegal damage to their trademarks. ${ }^{123}$

According to this argument a negligence based system would serve better the delicate balance between protection of copyright, access to information, and freedom of expression that the intermediary liability conundrum online entails. As long as they undermine the knowledge and take-down mechanism in place, filtering and monitoring obligations would by default cause chilling effects over freedom of information. As Van Eecke mentioned, "the notice-and-take-down procedure is one of the essential mechanisms through which the eCommerce

\footnotetext{
${ }^{121}$ Netlog, supra note 77 , at $§ 50$.

122 See Directive 2001/29/EC, supra note 14, at Recital 46.

${ }^{123}$ Google France SARL and Google Inc. v. Louis Vuitton Malletier SA, C-236/08, Google France SARL v. Viaticum SA and Luteciel SARL (C-237/08) and Google France SARL v. Centre national de recherche en relations humaines (CNRRH) SARL and Others, C-238/08, joined cases, $\S 123$ (CJEU, 23 March 2010) (Advocate General Opinion).
} 
Directive achieves a balance between the interests of rightholders, online intermediaries and users." ${ }^{124}$ Although imperfect as it is, a notice an-take-down mechanism embeds a fundamental safeguard for freedom of information as long as it forces intermediaries to actually consider the infringing nature of the materials before coming down with a final decision whether to take them down.

\section{b. On Protection of Personal Data}

Apparently, the unqualified deployment of filtering and monitoring obligation will impinge also on the service users' right to protection of personal data. In the SABAM cases, the ECJ has authoritatively already outlined the inappropriacy of these measures against fundamental rights also in this scenario. As the ECJ concluded,

requiring installation of the contested filtering system would involve the identification, systematic analysis and processing of information connected with the profiles created on the social network by its users. The information connected with those profiles is protected personal data because, in principle, it allows those users to be identified. ${ }^{125}$

Admittedly, the Netlog's Court does not fully explain how exactly such processing constituted a limitation of the right to data protection, or why, if it did constitute such a limitation, the Data Protection Directive would not legitimize the processing of personal data by Netlog. ${ }^{126}$ However, the ECJ has overcome his traditional reluctance in getting involved in any actual balancing of conflicting rights and established for the first time - in Scarlet and Netlog - a "fundamental right to the protection of personal data, which is not fairly balanced with copyright holders' rights when a mechanism requiring the systematic processing of personal data is imposed in the name of the protection of intellectual property." 127 Supposedly, secrecy of communication or the right to respect for private life ${ }^{128}$ could be also impinged upon by filtering technologies, according to the European Court of Human Rights, which tends to be critical of systems to intercept communications, especially when they monitor content of communications. ${ }^{129}$

\footnotetext{
${ }^{124}$ Van Eecke, supra note 65, at 1479-1480

125 Netlog, supra note 84 , at $\S 49$.

${ }^{126}$ See Gloria González Fuster, Balancing Intellectual Property against Data Protection: a New Right's Wavering Weight, 14 IDP 34, 44 (May 2012); Kulk and Borgesius, supra note 113, at 793.

${ }^{127}$ Fuster, supra note 126, at 37. See also L. Ferola, Diritto D'autore vs. Diritto alla Riservatezza: alla Ricerca di un Equo Bilanciamento nella Rete. I casi Peppermint, FAPAV e Scarlet, in I DIRITTI NELLA «RETE» DELLA RETE 67 (F. Pizzetti ed., UTET 2011).

${ }^{128}$ See Charter, supra note 114 , at Art. 7.

${ }^{129}$ See Kulk and Borgesius, supra note 113, at 793-794.
} 


\title{
c. On Freedom of Business and European Innovation
}

Finally, among the tsunami of negative reactions and unfulfilled expectations, ${ }^{130}$ residual critiques point at the negative externalities on innovation that this new regime would have. No monitoring obligations remove barriers to innovation by making cheaper for platforms to enter and compete in the market. This proposal would force intermediaries to develop and deploy costly technology to cope with EU law, therefore backing up property owners' attempts to leverage their hold-out power to block progress. These anti-competitive behaviours have repeatedly applied to property at large, ${ }^{131}$ but surfaced especially often throughout the history of copyright. ${ }^{132}$ The ECJ emphasized the economic impact on ISP of filtering and monitoring obligations. The ECJ assumed that monitoring all the electronic communications made through the network, without any limitation in time, directed to all future infringements of existing and yet to

\begin{abstract}
${ }^{130}$ See EC Failed to \#FixCopyright: Stop 'RoboCopyright' and Ancillary Copyright \& Start to Focus on Users and Creators, Copyright for Creativity, September 14, 2016, http://copyright4creativity.eu/2016/09/14/ec-failed-to-fixcopyright-stop-robocopyright-andancillary-copyright-start-to-focus-on-users-and-creators; Alberto Bellan, Wikimedia, EDRI, and Others Call for EU Copyright Package to Uphold DSM Fundamental Principles, IPKAT, September 13, 2016, http://ipkitten.blogspot.fr/2016/09/wikimedia-edri-and-others-call-foreu.html. Quite understandably, consistent negative reactions came from multiple voices in the Silicon Valley and the United States. See eg Jeremy Malcom, European Copyright Leak Exposes Plans to Force the Internet to Subsidize Publishers, EFF Blog, August 26, 2016, https://www.eff.org/deeplinks/2016/08/european-copyright-leak-exposes-plans-force-internetsubsidize-publishers; David Meyer, Why Europe's New Copyright Proposals Are Bad News for the Internet, FORTUNE, September 14, 2016, http://fortune.com/2016/09/14/europe-copyrightgoogle; Natasha Lomas, EU Digital Copyright Reform Proposals Slammed as Regressive, TECHCRUNCH, September 14, 2016, https://techcrunch.com/2016/09/14/eu-digital-copyrightreform-proposals-slammed-as-regressive; Cory Doctorow, The EU Tried to Craft a Sane $21^{\text {st }}$ Century Copyright and Failed Miserably, BINGBoing, September 14, 2016, https://boingboing.net/2016/09/14/the-eu-tried-to-craft-a-sane-2.html.
\end{abstract}

${ }^{131}$ See Carol M. Rose, The Comedy of the Commons: Custom, Commerce, and Inherently Public Property, 53 U. CHI. L. REV. 711 (1986), at 749-50, 752 (discussing how large public projects such as highways or railroads are vulnerable to the hold-out power of single property owners).

132 See Hannibal Travis, Building Universal Digital Libraries: An Agenda for Copyright Reform, 33 PEPP. L. REV. 761, 786-792 (2006) (sketching a quick history of hold outs on cultural technological advancements); White-Smith Music Publishing Company v. Apollo Company, 209 U.S. 1 (1908) (piano rolls); Fortnightly Corp. v. United Artists, 392 U.S. 390 (1968) (cable television); Amstrad Consumer Electronics plc v. The British Phonographic Industry Ltd [1986] FSR 159 (CA) (tape recorders); Sony Corp. of Am. v. Universal Studios, Inc., 464 U.S. 417, 429 (1984) (VHS recorder); Twentieth Century Music Corp. v. Aiken, 422 U.S. 151 (1975) (radio); A\&M Records, Inc. v. Napster, Inc., 239 F.3d 1004 (9th Cir. 2001) (peer to peer software); Metro-Goldwyn-Mayer Studios Inc. v. Grokster, Ltd., 545 U.S. 913 (2005) (peer to peer software); UMG Recordings, Inc. v. MP3.com, Inc., 92 F. Supp. $2 d 349$ (S.D.N.Y. 2000) (mp3 music format); Perfect 10, Inc. v. Amazon.com, Inc., 508 F.3d 1146 (9th Cir. 2007) (search engines and digital thumbnails); Vorschaubilder, I ZR 69/08 (Bundesgerichtshof, April 29, 2010) (Germany) (ruling that Google Image Search does not infringe copyright); Capitol Records, LLC v. ReDigi, Inc., 934 F. Supp. 2d 640 (S.D.N.Y., March 30, 2013) (deciding that users do not have the right to resell digital music on ReDigi, even though it features an innovative cloud service technology that verifies the legitimacy of a digital music file before it can be uploaded for storage). 
create works "would result in a serious infringement of the freedom of the hosting service provider to conduct its business." 133 Hosting providers' freedom of business would be disproportionally affected since an obligation to adopt filtering technologies would require the ISP to install a complicated, costly and permanent system at its own expense. ${ }^{134}$ In addition, according to the ECJ, this obligation would be contrary to Article 3 of the Enforcement Directive, providing that "procedures and remedies necessary to ensure the enforcement of the intellectual property rights [...] shall not be unnecessarily complicated or costly [and] shall be applied in such a manner as to avoid the creation of barriers to legitimate trade." 135

Whether technology is too costly - therefore limiting market incentives for present market players - might be up to debate as shown by the Allostreaming case in France and the Dafra case in Brazil. ${ }^{136}$ In both cases Google so-called "technical defense" was refuted by the courts on the basis of expert-testimony reports to the contrary. ${ }^{137}$ YouTube content ID alternatives-such us Audible Magic, which is claimed to be a cheap solution - are widely available on the market. ${ }^{138}$ However, the proposed legislation might have unforeseen effects that would favor established market players, rather than competition in the content market online. In fact, negative externalities upon innovation would hit harder new market entrants, which will have to bear additional costs and do not own any proprietary recognition technology. In particular, the European tech industry will be at a disadvantage as it should licence filtering technologies either from Google/YouTube - which might rather keep it for its exclusive use - or other US companies such as Audible Magic. As most established market players are USbased, this proposal might be once again a bad trade-off for European companies-and push the Digital Single Market further away, rather than promoting it.

\section{On Empirical Evidence and the Value-Gap}

There is finally an overarching concern with the appropriateness of this reform that would question its fundamental goal. As mentioned, the introduction of Article 13 would be justified by the necessity of closing the so-called "value gap." The idea of a "value gap" echoes a discourse almost exclusively fabricated by the music and entertainment industry. Apparently, this rhetorical device was coined for the first time in music industry global reports and never used

\footnotetext{
${ }^{133}$ Netlog, supra note 77 , at $\S 46$.

${ }^{134} I d$.

${ }^{135}$ See Enforcement Directive, supra note 20, at Art. 3.

136 See APC, supra note 74; Dafra, supra note 74.

${ }^{137} I d$.

${ }^{138}$ See Audible Magic, http://www.audiblemagic.com.
} 
elsewhere. ${ }^{139}$ Being a partisan fabrication, this rhetoric Seems scarcely concerned with empirical evidence. The Draft Directive's Impact Assessment admits it quite plainly:

economic impacts are mostly assessed from a qualitative point of view, considering how the different policy options would affect the negotiations between those creating or investing in the creation of content and those distributing such content online. The limited availability of data in this area [. . .] did not allow to elaborate a quantitative analysis of the impacts of the different policy options. ${ }^{140}$

And, again, the European Copyright Society reinforced this point by noting: "we are disappointed to See that the proposals are not grounded in any solid scientific (in particular, economic) evidence." 141 Actually, there is no clear evidence on the effects of copyright infringement in the digital environment, the scale of it, the nature of it, or the effectiveness of more aggressive enforcement strategies. In an authoritative report commissioned by the UK government, Digital Opportunity. A Review of Intellectual Property and Growth, Professor Ian Hargreaves noted:

The question is: in a digital world, where copying and distribution are more or less free, what does an effective regime look like? No one doubts that a great deal of copyright piracy is taking place, but reliable data about scale and trends is surprisingly scarce. Estimates of the scale of illegal digital downloads in the UK ranges between 13 per cent and 65 per cent in two studies published last year. $A$ detailed survey of UK and international data finds that very little of it is supported by transparent research criteria. Meanwhile sales and profitability levels in most creative business sectors appear to be holding up reasonably well. We conclude that many creative businesses are experiencing turbulence from digital copyright infringement, but that at the level of the whole economy, measurable impacts are not as stark as is sometimes suggested. ${ }^{142}$

The Hargreaves Report hints at a key question of the debate over digital piracy. Copyright policies to tackle piracy should be based on hard and transparent evidence.

Actually, in contrast, a Report commissioned by the European Commissionand delivered in May 2015 but released only recently following an access to document request from a Pirate Party's $\mathrm{MEP}^{143}$ — showed that there is no "robust

\footnotetext{
${ }^{139}$ See Husovec, supra note 35.

${ }^{140}$ European Commission, Commission Staff Working Document, Impact Assessment on the modernisation of EU copyright rules, 14 September 2016, SWD(2016) 301 final, PART 1/3, pp. 136.

${ }^{141}$ European Copyright Society, General Opinion on the EU Copyright Reform Package (24 January 2017), at 5.

142 IAN Hargreaves, Digital OpPORTUnity. A ReVIEW OF InTEllectual Property AND Growth 10 (May 2011) (emphasis added). See also Joe Karaganis, Rethinking Piracy, in MEDIA PIRACY IN EMERGING ECONOMIES 4, 4-11 (Joe Karaganis ed., Social Science Research Center 2011) (making the same point)

${ }^{143}$ See Julia Reda, What the Commission Found Out About Copyright Infringement but 'Forgot' to Tell Us, JULIAREDA.EU, September 20, 2017, https://juliareda.eu/2017/09/secret-copyrightinfringement-study.
} 
statistical evidence of displacement of sales by online copyright infringements." 144 Instead, at least in the case of video games, "the estimated effect of illegal online transactions on sales is positive-implying that illegal consumption leads to increased legal consumption." ${ }^{145}$ In sum, the Report concludes,

the main contribution to the existing literature is the finding on displacement rates for recent top films and the lack of a robust (positive) displacement rate for films / TV-series in general, music, books and games despite the carefully developed questionnaire and the application of econometric analysis. ${ }^{146}$

Crafting important pieces of a reform that should promote the European Digital Single Market on the assumption of a "value gap" to close might be the result of tunnel vision and a contradiction in terms. It does endorse a rhetorical approach that would be apparently looking backwards, rather than forward. The Internet, digitization, platform and sharing economies might be an opportunity for creators, rather than the opposite. The Commission-in setting up its reformation process, goals, and vision - might have chosen the alternative path of emphasizing the "added value" of technological innovation, rather than the "value gap." To this end, clear empirical evidence should have been carefully reviewed to consider whether creators - and the creative market as a wholehave been slowly withering or rather flourishing. So far, independent empirical evidence supporting the present enforcement strategy was never provided. Contrary evidence that might emphasize positive externalities for creativity of the Internet, digitization, and platforms was equally never considered. Actually, this evidence is plenty. The literature has shown to a certain degree of consistency that there is in fact an added value to promote, rather than a value gap to close. ${ }^{147}$ Empirical studies have shown that in the digital environment, the sky is raising, rather than falling, as far as creative industries are concerned. ${ }^{148}$ As the economist Joel Waldfogel has recently proved:

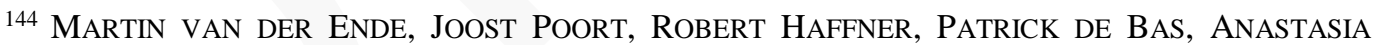
YAgafarova, SOPHIE ROHLFS, HARRY VAN TIL, Estimating Displacement RATES OF COPYRIGHTED CONTENT IN THE EU: FINAL REPORT 7 (European Commission, May 2015).

${ }^{145} I d$., at 14.

${ }^{146}$ Id., at 8 .

147 See Giancarlo F. Frosio, Digital Piracy Debunked: A Short Note on Digital Threats and Intermediary Liability, 5(1) INTERNET POLICY REVIEW 1-22 (2016), https://policyreview.info/articles/analysis/digital-piracy-debunked-short-note-digital-threats-andintermediary-liability.

${ }^{148}$ See Michael Masnick and Michael Ho, The Sky is Rising: A Detailed Look at the State of the Entertainment Industry 3 (Floor 64, January 2012), supra noting the market for music, film and videos, video games, and books has been blooming through the last decade with the value of the worldwide entertainment industry growing of nearly fifty percent, employment in the U.S. entertainment sector rising by nearly twenty percent, the amount of new content being produced worldwide growing at a tremendous rate in any area of the entertainment industry and, finally, more importantly, the total U.S. household spending that went to entertainment growing of fifteen
} 
Yet despite the sharp revenue reductions for recorded music, as well as threats to revenue in some other traditional media industries, other aspects of digitization have had the offsetting effects of reducing the costs of bringing new products to market in music, movies, books, and television. On balance, digitization has increased the number of new products that are created and made available to consumers. Moreover, given the unpredictable nature of product quality, growth in new products has given rise to substantial increases in the quality of the best products and therefore the benefit of these new products to consumers. ${ }^{149}$

Again, piracy have been construed by some as an innovation policy, forcing the market to adapt to user needs. ${ }^{150}$ And, the market did in fact adapt, offering new and more affordable ways to enjoy creativity. Overlooking this empirical evidence - or at least moving forward without an impact statement that would consider all evidence and possible narratives - might result into a reform that will prove obsolete before being implemented, possibly detrimental for the Digital Single Market, rather than beneficial. ${ }^{151}$

\section{CONCLUSIONS}

As part of its recent proposal to adapt copyright to the Digital Single Market ("DSM"), the European Commission would like to introduce a set of new obligations for information society service providers to deal with certain uses of protected content by online services. As such, redistributing resources to creators - by promoting functioning licencing agreements - would be a laudable goal. Also, narrow and specific duties of care to detect and prevent infringing activities would be within the scope of EU law. However, the means to reach these goals as deployed in this proposal-together with the shaky empirical foundations of the notion of value gap - can find little support and justification within the EU legal system. In addition to (I) clarity concerns specific to this proposal, the introduction of monitoring obligations for online intermediaries would raise more general critiques in terms of (II) consistency with other portions of the EU acquis, (III) appropriacy and proportionality.

percent). See also Joel Waldfogel, Is the Sky Falling? The Quality of New Recorded Music Since Napster, VOX, November 14, 2011, http://www.voxeu.org/index.php?q=node/ 7274.

149 Joel Waldfogel, 'How Digitization Has Created a Golden Age of Music, Movies, Books, and Television’ (2017) 31(3) The Journal of Economic Perspectives 195, 195.

150 See Adrian Johns, Piracy: The Intellectual Property WARs From Gutenberg to GATES (U. of Chicago Press, 2010).

${ }^{151}$ Scholarly projects have been trying to establish a body of evidence that allows better decision making in the contested copyright policy field. See The Copyright Evidence Wiki: Empirical Evidence for Copyright Policy (Theo Koutmeridis, Kris Erickson, Martin Kretschmer (eds.), CREATe Centre: University of Glasgow, 2015), www.CopyrightEvidence.org (accessed December 15, 2016). The EU Parliament might have taken notice of the necessity to legislate about copyright law on the basis of clear empirical evidence by dedicating the $6^{\text {th }}$ edition of the EUhackathon challenge to visualizing empirical evidence for copyright reform. As part of this challenge, a number of software developers have been called to develop tools to visualize copyright empirical evidence. See EUhackathon, 15-16 November 2016, http://2016.euhackathon.eu. 
First, wording in this proposal would lack in clarity and make hard to predict the implications of the implementation of the proposal. In particular, (1) the notion of large amounts of works that the targeted providers are supposed store and provide access to - and the scope of application of the new provisionbecomes impossible to determine; (2) the notion of works in Art. 13 must be qualified as copyright-protected works, otherwise the category of online services covered by the provision would be expanded by including in the large amount of works also unprotected works stored or to which public access is provided; (3) Recital 38(1) would imply that intermediaries storing and providing public access to protected works would be communicating to the public, thus making hosting providers directly liable, rather than secondary liable as commonly understood.

Second, introducing an obligation for intermediaries to develop and deploy filtering systems-therefore de facto monitoring their networks-would apparently create systemic inconsistencies. In particular, the proposal would (1) contradict the present intermediary liability exemption regime - in particular the general no-monitoring obligation set out in Article 15 of the eCommerce Directive; (2) conflict openly with consistent - and unambiguous-jurisprudence of the European Court of Justice, confirming that there is no room for general proactive monitoring and filtering mechanisms under EU law; (3) deploy a strict liability regime, rather than a negligence-based regime, making knowledge and take-down irrelevant for copyright purposes, de facto tearing apart the eCommerce Directive, which will be however still in full force; (4) set up a redress mechanism for filtering absent an EU-wide legislatively mandated noticeand-take-down system; and (5) be inconsistent with the EU Charter of Fundamental Rights.

Third, the numerous systemic inconsistencies that the proposal would bring about reflect also on the appropriacy and proportionality of the introduction of filtering obligations. Consistent jurisprudence of the ECJ highlighted that the deployment of filtering and monitoring technologies would be inappropriate by disproportionally favouring property rights against other fundamental rights, including (1) users' freedom to receive and impart information as automated infringement assessment system cannot distinguish adequately between unlawful content and lawful content, especially in the case of exceptions and limitations and public domain works; (2) users' right to protection of personal data as filtering system would involve the identification, systematic analysis and processing of information connected with the profiles created on the social network by its users; (3) hosting providers' freedom of business as an obligation to adopt filtering technologies would require the ISP to install a complicated, costly and permanent system at its own expense. The notion of value gap - and the present reform package - is apparently based on content industry assumptions, rather than independent empirical evidence. Moving forward without an impact statement that would consider all evidence and possible narratives - might result into a reform that will prove obsolete before being implemented, possibly detrimental for the Digital Single Market.

The directive proposal was submitted for review to the EU Parliament and the Council. There is still room for adjustment, which would be very much welcome. 
The reform endorses a reaction to the platform economy which is apparently based on content industry assumptions, rather than independent empirical evidence. Absent empirical justification, a reform that would upset deeply traditional notions governing copyright and intermediary liability policy can hardly be "fit for purpose." The textual confusion and incoherence, the systemic inconsistencies and the inappropriacy of the measures that will bring about make this reform in its present form a bad-trade off. However, it is not beyond repair. Once references to "communication to the public" and "content recognition technologies" are expunged from the text and other textual misunderstandings fixed as well, Recital 37-39 and Article 13 of the proposal could serve as level playing field to promote monetization agreements between creators and online services.

Rather than imposing filtering and monitoring obligations on hosting providers that will conflict with EU law in force and fundamental rights, the reform might formalize an obligation to conclude monetization agreements between content creators and online platforms. This would also serve as fair compensation for a UGC exception that could be coupled with the monetization agreements. ${ }^{152}$ This mandatory monetization agreements could be entered by individual creators or collective management organizations for entire repertoires. According to Google policy, for example, with the deployment of Content ID, if there is a match between an uploaded file and a reference file, one option is to monetize a matched video for the copyright owner by running advertisements against it - other options are to block the video or track the video's viewership statistics. ${ }^{153}$ Rather than imposing blocking of allegedly infringing files, platforms should be only under the obligation of providing content creators with the revenue stream coming from advertising run against the content. This would

\footnotetext{
${ }^{152}$ See Martin Senftleben, Christina Angelopoulos, Giancarlo Frosio, Valentina Moscon, Miquel Peguera, Ole Rognstad, The Recommendation on Measures to Safeguard Fundamental Rights and the Open Internet in the Framework of the EU Copyright Reform (October 17, 2017), at 23-24, available at ssrn.com/abstract $=3054967$, EUROP. INTEL. PROP. REV. (forthcoming 2017) (proposing fair compensation for a new copyright exception for the creation of users' remixes and mash/ups and their communication via UGC platforms). Actually, fair compensation for privileged uses belongs to a long-standing EU copyright law's tradition. See Directive 2001/29/EC, supra note 14, at Recital 35 and Art. 5(2)(a) and (b). See also, for examples and discussions on the introduction of a UGC exception, An Act to amend the Copyright Act, 2010, Bill C-32 (Can.), Art. 22 (introducing a UGC exception in Canadian law); Peter Yu, Can the Canadian UGC Exception Be Transplanted Abroad?, 26 INTELL. ProP. J. 177 (2014) (discussing also a Hong Kong proposal for a UGC exception); Warren B. Chik, Paying it Forward: The Case for a Specific Statutory Limitation on Exclusive Rights for User-Generated Content Under Copyright Law, 11 J. MARShall ReV. InTEll. ProP. L. 240 (2011); Daniel Gervais, The Tangled Web of UGC: Making Copyright Sense of User-Generated Content, 11 VAND. J. ENT. \& TECH. L. 841, 861-869 (2009); Debora Halbert, Mass Culture and the Culture of the Masses: A Manifesto for User-Generated Rights, 11 VAND. J. ENT. \& TECH. L. 921, 934-953 (2009); Mary W. S. Wong, "Transformative" User-Generated Content in Copyright Law: Infringing Derivative Works or Fair Use?, 11 VAND. J. ENT. \& TECH. L. 1075 (2009); Edward Lee, Warming Up to UserGenerated Content, 2008 U. ILL. L. REV. 1459, 1462 (2008).

153 See YouTube, How Content ID Works, https://support.google.com/youtube/answer/2797370?hl=en.
} 
boost revenue streams for creators according to the popularity of their worksand quantity of reuses. In contrast, it seems counter-intuitive to block access to content that if made available to the public would compensate creators the more it is widespread. Rather than fighting technological change-driving cost of content reproduction close to zero, having distribution costs sustained by third parties, rather than creators, and accurately tracking online uses-policy reform should embrace it. As Francis Gury noted,

the central question of copyright policy [ . . ] implies a series of balances: [ . . ] [d]igital technology and the Internet [. . .] have given a technological advantage to one side of the balance, the side of free availability, the consumer, social enjoyment and short-term gratification. History shows that it is an impossible task to reverse technological advantage and the change that it produces. Rather than resist it, we need to accept the inevitability of technological change and to seek an intelligent engagement with it. There is, in any case, no other choiceeither the copyright system adapts to the natural advantage that has evolved or it will perish. ${ }^{154}$

At least in a scenario dealing with content uploaded on large UGC platforms - as that considered by Art.13 - moving towards an arrangement that resembles closely a liability rule or an apportionment of profit, rather than the traditional copyright principle of exclusivity, might turn to be a win-win situation, both for creators and users. ${ }^{155}$ In any event, a knowledge-and-takedown mechanism will be still available under the eCommerce Directive. The value-gap would be addressed, and internal inconsistency avoided.

\footnotetext{
${ }^{154}$ Francis Gurry, WIPO General Director, Speaker, Blue Sky Conference: Future Directions in Copyright Law at Queensl. Univ. of Tech., Brisbane, Australia, 25 February 2011, transcript available at http://www.wipo.int/about-wipo/en/dgo/speeches/dg blueskyconf_11.html.

${ }^{155}$ See eg, Giancarlo F. Frosio, Rediscovering Cumulative Creativity from the Oral-Formulaic Tradition to Digital Remix: Can I Get a Witness? 13(2) J. MARSHALl REV. INTELL. ProP. L. 341, 390-393 (2014); Christophe Geiger, Promoting Creativity through Copyright Limitations: Reflections on the Concept of Exclusivity in Copyright Law, 12 VAND. J. ENT. TECH. L. 515, 547 (2011) (proposing the implementation of a "limitation-friendly copyright protection, even if doing so would require rethinking the principle of exclusivity [and] the scope of copyright is reduced to the prevention of the mere copy of the work, and does not cover the creative re-uses"); DAVID LANGE \& JEFFERSON H. POWELl, No LAW: INTELleCTUAL PROPERTY IN THE IMAGE OF AN ABSOlute FIRST AMENDMENT 179, 384 fn. 37 (Stanford Law Books 2009); Jed Rubenfeld, The Freedom of Imagination: Copyright's Constitutionality, 112 YALE L. J. 1, 1 (2002).
} 